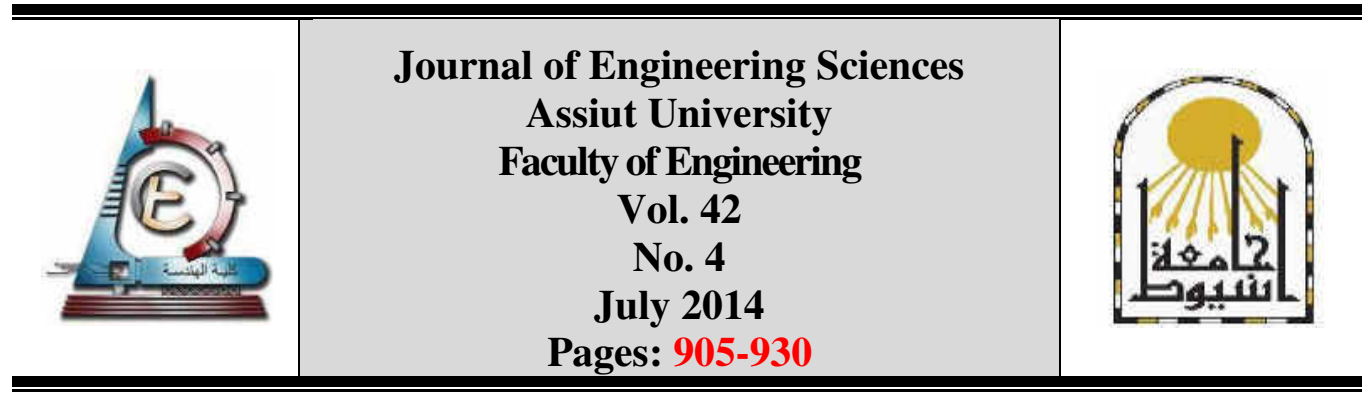

\title{
SOIL-STRUCTURE INTERACTION EFFECTS ON SEISMIC RESPONSE OF MULTI-STORY BUILDINGS ON RAFT FOUNDATION
}

\author{
Shehata E. Abdel Raheem ${ }^{1}$, Mohamed M. Ahmed ${ }^{2}$ and Tarek M.A. Alazrak ${ }^{3, *}$ \\ ${ }^{1}$ Assoc. Prof., Civil Eng. Department, Faculty of Engineering, Assiut University, Egypt and in \\ a secondment to Taibah University, Madinah Munawarh, KSA. shehataraheem@yahoo.com \\ ${ }^{2}$ Assoc. Prof., Civil Eng. Department, Faculty of Engineering, Assiut University, Egypt \\ ${ }^{3}$ M.Sc. Graduate Student, Civil Eng. Department, Faculty of Engineering, Assiut Univ., Egypt
}

Received 17April 2014; accepted 5 June 2014

\begin{abstract}
The investigation on the energy transfer mechanism from soils to buildings during earthquakes is critical for the design of earthquake resistant structures and for upgrading existing structures. Thus the need for research into Soil-Structure Interaction (SSI) problems is greater than ever. Moreover, recent studies show that the effects of SSI may be detrimental to the seismic response of structure and neglecting SSI in analysis may lead to un-conservative design. Despite this, the conventional design procedure usually involves assumption of fixity at the base of foundation neglecting the flexibility of the foundation, the compressibility of soil mass and consequently the effect of foundation settlement on further redistribution of bending moment and shear force demands. Hence the soil-structure interaction analysis of multi-story buildings is the main focus of this study; the effects of SSI are analyzed for typical multi-story building resting on raft foundation. Three methods of analysis are used for seismic demands evaluation of the target moment resistant frame buildings: equivalent static load (ESL); response spectrum (RS) methods and nonlinear time history (TH) analysis with suit of nine time history records. Three-dimensional FEM model is constructed to analyze the effects of different soil conditions and number of stories on the vibration characteristics and seismic response demands of building structures. Numerical results obtained using soil structure interaction model conditions are compared to those corresponding to fixed-base support conditions. The peak responses of story shear, story moment, story displacement, story drift, moments at beam ends, as well as force of inner columns are analyzed. The analysis results of different approaches are used to evaluate the advantages, limitations, and ease of application of each approach for seismic analysis.
\end{abstract}

Keywords: Soil-structure interaction; Seismic design; Egyptian building code; Time history; Dynamic analysis; Moment resistant multi-story building; Raft foundation.

"Corresponding author.

Email address: eng.tarek2011@gmail.com 
Shehata E Abdel Raheem et al., Soil-structure interaction effects on seismic response of multi....

\section{Introduction}

Over the past 40 years, considerable progress has been made in understanding the nature of earthquakes and how they damage structures, and in improving the seismic performance of the built environment [1]. However, much remains unknown regarding the prevention or mitigation of earthquake damage in worldwide, leaving room for further studies. During past and recent earthquakes, it is realized that the soil-structure interaction (SSI) effects play an important role in determining the behavior of building structures. The experienced seismic excitation can be considered as function of the fault rupture mechanism, travel path effects, local site effects, and SSI effects [2]. Irrespective of the structure, the local soil conditions can dramatically influence the earthquake motion from the bedrock level to the ground surface, through their dynamic filtering effects. One example is the 1985 Mexico City earthquake where deep soft soils amplified the ground motion and modified the frequency of ground shaking [3-4]. Similar behavior was observed during the 1989 Loma Prieta earthquake, in which the sections of the Cypress freeway in Oakland collapsed due to the soil-related motion amplification [1]. The seismic soil structure interaction of multi-story buildings becomes very important after the destruction of recent major earthquakes [5-6]. For the structure founded on the soil, the motion of the base of the structure will be different from the case of fixed base [7], because of the coupling of the structure-soil system. It is true that taking the soil into account when calculating the seismic response of the structure does complicate the analysis considerably. It also makes it necessary to estimate additional key parameters, which are difficult to determine, such as the dynamic properties of the soil such as site response, radiation damping and kinematic interaction [8].

The investigation on the energy transfer mechanism from soils to buildings during earthquakes is critical for the design of earthquake resistant structures and for upgrading existing structures. Thus the need for research into Soil-Structure Interaction (SSI) problems is greater than ever. Moreover, recent studies show that the effects of SSI may be detrimental to the seismic response of structure and neglecting SSI in analysis may lead to un-conservative design [9]. Despite this, the conventional design procedure usually involves assumption of fixity at the base of foundation neglecting the flexibility of the foundation, the compressibility of soil mass and consequently the effect of foundation settlement on further redistribution of bending moment and shear force demands. Hence, this study aims to study the soil-structure-interaction for multi-story buildings on raft foundation; evaluate the approach of Egyptian Code seismic provisions, ECP-201[10] for analysis methods during the seismic design of buildings; to discuss the alternative solutions for cases wherein existing provisions do not lead to satisfactory results and to quantify the effect SSI on the structural response so that designers can be aware of the likely impact of their decisions. Time History analysis (TH) has been performed to evaluate Equivalent Static Load (ESL) and the Response Spectrum (RS) analysis methods; a set of time history records has been used. A parametric study with different approaches of analysis methods; design parameters of the underneath soil condition and number of stories is carried out to evaluate the building vibration characteristics and seismic demands including the fundamental period, total base shear, story displacements, story drifts, moment at beam ends and force of inner columns. The results show that SSI has a significant influence on the seismic response demands. 


\section{Egyptian Code Seismic Provisions (ECP-201 2008)}

The great losses due to Cairo earthquake on October 1992 (Dahshour earthquake Ms 5.9) were mainly related to the fact that at the time of construction, the buildings were designed to resist only vertical loads and had insufficient lateral resistance [5, 11]. Thus, the columns and beam column connections were found to have inadequate shear capacity, ductility and confinement in plastic hinges [12]. This earthquake illustrated the vulnerability of the building stock, especially for older structures, due to design, detailing, construction and maintenance issues [13-15]. So there is an urgent need for assessment of existing buildings in terms of seismic performance and continuously upgrades the seismic codes for the design of new buildings. The design of structures for earthquakes became a major demand enforced in the Egyptian design codes that motivated the Ministry of Housing and Buildings to update the Egyptian codes regularly, to take into account the seismic loads into consideration. Since October 1992, a set of Egyptian codes have been released to prevent buildings collapse and/or control major damages of structural elements. Many advances in earthquake engineering have been made from the observation of the performance of real structures that have been subject to a severe earthquake, analytical modeling, including Finite Element Analysis; FEA, has an important role, but its limitations must be recognized. For many engineered structures, satisfactory seismic performance requires careful attention to the analysis, design, detailing, and good construction practice. Safety is thus achieved by the successful integration of analysis, design and construction.

Building code restrictive seismic design provisions and building systems type and configuration have remarkable implications on seismic performance of reinforced concrete moment framed structures [5]. The specifications permit the designer to utilize a variety of methods for seismic analysis that range from simple equivalent static analysis to complex nonlinear dynamic analysis (UBC [16], AIJ [17], SEAOC [18], IBC [19], EC8 [20], ASCE [21], ECP-203[22], ECP-201[10]). For building structures, it is common practice to utilize a simplified approach, such as equivalent static load. This approach has several shortcomings, which have been accepted due to its simplicity and a lack of alternative practical approaches [5]. Such approach may be regarded as force-based since the methods primary emphasis is on the forces within the structure. In recent years, there has been a shift of attention away from linear methods of seismic analyses to nonlinear methods which put emphasis on the displacements within the structure. Thus, nonlinear analysis methods that are capable of realistically predicting the deformations imposed by earthquakes on structures are needed. In response to this need, nonlinear static analysis procedures have appeared in national resource documents such as the ATC-40 report on seismic evaluation and retrofit of concrete buildings [23-24] and the FEMA-356 prestandard on seismic rehabilitation of buildings [25-26]. Such analysis methods are useful for predicting inelastic displacement capacities while simultaneously offering a compromise between the oversimplification of linear static analysis and the inherent complexity of nonlinear dynamic analysis. The latest Egyptian Code for Loads and Forces, ECP-201 [10] and most of the international participating building codes, depends on the traditional approach of equivalent static load method as a main method for evaluating seismic actions on symmetrical buildings (UBC [16], AIJ [17], EC8 [20], ECP-201 [10]). 
For non-symmetrical buildings, the ECP-201 [10] recommended the response spectrum method to be used for building seismic analysis and design, which considered more accurate method of analysis than the equivalent static load method [27-28].

Egypt had suffered numerous destructive earthquakes such as Kalabsha earthquake (1981, Ms 5.4) near Aswan city and the High dam, Dahshour earthquake (1992, Ms 5.9) near Cairo city and Aqaba earthquake (1995, Ms 7.2). As the category of earthquake damage includes all the phenomena related to the direct and indirect damages, the Egyptian authorities do a great effort to mitigate the earthquake disasters. The seismicity especially at the zones of high activity is investigated and the soil condition, soil amplification, soil structure interaction, liquefaction and seismic hazard are carried out in particular the urbanized areas. All these parameters are integrated to obtain the Egyptian building code which is valid to construct buildings resisting damages and consequently mitigate the earthquake disasters. A prevailing common conclusion of several studies is that SSI could produce significant effects on the seismic response of structures: both beneficial and detrimental effects were reported. Nevertheless, utilization of the findings of these research efforts in national and international design codes and in routine design calculations is still very rare if not absent.

\section{Seismic analysis procedures}

In the preliminary design process, equivalent static seismic forces are used to determine the design internal forces of structural members using linear elastic analyses of structure and, in turn, determine the design member strength demands. Such static seismic forces are simply determined corresponding to the elastic design acceleration spectrum divided by a structural strength reduction factor particularly called: the response modification factor $R$ (ECP-201[10], UBC [16]); the structural behavior factor, $q$ (EC8 [20]); or the structural factor, $D_{s}$ (AIJ [17]). Usually, the elastic design spectrum, which is often related to $5 \%$ or $10 \%$ Probability of Exceedance $(P O E)$ in 50 years, is defined smoothly as a reasonable representation of the seismic action demand on the structure at the site of interest. The adopted strength reduction factor is thus intended to represent an expected inelastic response demand or expected damage level demand of the whole structure, which may be induced during earthquake excitation [29].

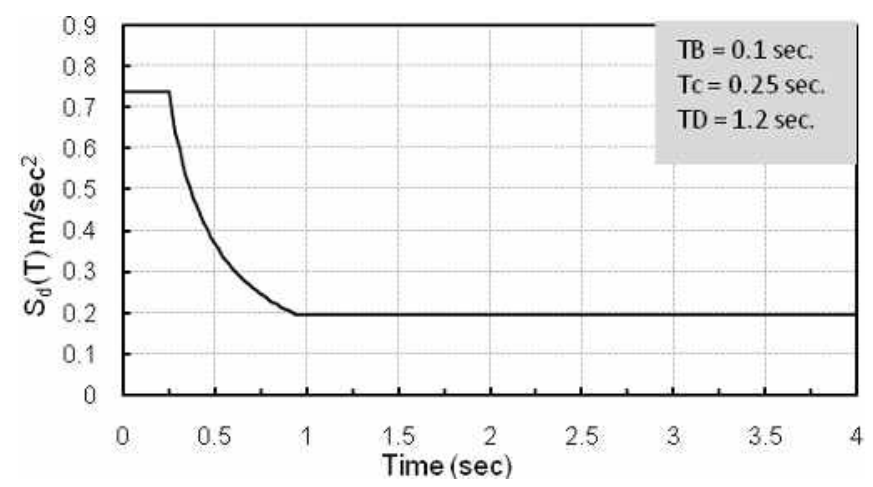

Fig. 1. ECP-201 [10] design response spectrum 


\subsection{Equivalent static load (ESL) method}

According to the ECP-201 [10], the seismic base shear force, $F_{b}$, for each horizontal direction in which the building is analyzed, shall be determined using the following expression:

$F_{b}=S_{d}\left(T_{1}\right) \times \lambda \times W / g$

Where: $S_{d}\left(T_{1}\right)$ is the ordinate of the design spectrum at period $T_{1} ; T_{1}$ is the fundamental period of vibration of the building for lateral motion in the direction considered; $W$ is the total weight of the building, above the foundation level; $g$ is the gravity acceleration; $\lambda$ is the effective modal mass correction factor, the value of which is equal to: $\lambda=0.85$ for $T \leq$ $2 T_{\mathrm{C}}$, and $n>2$ stories, where $n$ is the number of stories; $T_{c}$ is the upper limit of the period of the constant spectral acceleration branch as shown in Fig. 1. The value of the fundamental period of vibration, $T$, is determined using the following expression:

$T=C_{t} \times H^{3 / 4}$

Where $C_{t}$ is a factor determined according to the structural system and building material and equal to 0.075 in case of moment-resistant space concrete frame; $H$ is the height of the building $(m)$ in meters; from the foundation or from the top of a rigid basement. The ordinate of the design spectrum, $S_{d}\left(T_{1}\right)$, can be determinate from:

$s_{d}(T)=\frac{2.5}{R} \times a_{g} \times \gamma \times S\left[\frac{T_{c}}{T}\right] \geq[0.2] \times a_{g} \times \gamma$

Where $a_{g}$ is the design ground acceleration for the reference return period; $T_{c}$ is the upper limit of the period of the constant spectral acceleration branch as shown in Fig. 1; $S$ is the soil factor. $\gamma$ is the importance factor. $R$ is the reduction factor according the statical system of the structure. The total base shear, $F_{b}$, shall be determined by applying horizontal forces $F_{i}$ to each story mass $m_{i}$ and shall be distributed as follows:

$F_{i}=\left[\frac{z_{i} \times W_{i}}{\sum_{j=1}^{n} z_{j} \times W_{j}}\right] \times F_{b}$

Where $F_{i}$ is the horizontal force acting on story $i ; F_{b}$ is the seismic base shear force (Eq. 1); $z_{i}, z_{j}$ are the heights of the masses $m_{i}, m_{j}$ above the foundation level respectively; $W_{i}, W_{j}$ are the weights of masses $m_{i}, m_{j} ; n$ is the number of stories above foundation level. Eq. 5 gives linear shear distribution depending on the story height.

\subsection{Modal response spectrum (RS) method}

The modal response spectrum analysis is applicable for all types of buildings, while the lateral force method of analysis has many restrictions on its use due to the 'fear' that it would provide un-conservative results in certain conditions; however, in spite of this disadvantage the method is still widely used due to its ease of application [30]. Response spectrum analysis includes sufficient modes of vibration to capture participation of at least $90 \%$ of the structure's mass in each of two orthogonal directions [31]. Fig. 1 shows the design response spectrum curve for current case study, it shall be noted that, ECP-201 [10] includes a damping coefficient in the elastic response spectra equations. Hence, no 
damping ratio has been used in the analysis of this method. As specified in most design codes, the shape of the target elastic acceleration spectrum is characterized by the seismic intensity expressed in terms of the expected design peak ground acceleration (PGA), $a_{g}$, and the effect of soil ground types expressed in terms of the response spectral periods $T_{b}$ and $T_{c}$. various values of $T_{b}$ and $T_{c}$ were considered corresponding to different soil ground types (from A-type of hard rock to D-type of soft soil).

Many codes recognize that the period of vibration from the simplified period-height equation is more realistic, having been directly obtained from the measured periods of vibration of buildings subject to earthquake ground motions, but that when higher modes are important (in tall and/or irregular structures) the modal response spectrum method gives a more realistic profile of the lateral forces. Hence, these codes (ECP-201 [10], NBCC [32], ASCE [21]) require the designer to check whether the modal base shear force is less than $85 \%$ of the base shear force from the equivalent static force method. If this is the case then the modal forces, but not the drifts, should be multiplied by $0.85 \mathrm{~V} / \mathrm{V}_{t}$ where $V$ is the base shear from the lateral force method and $V_{t}$ is the base shear from the required modal combination. Even when higher modes are not important and the designers are allowed to use the linear static method, but they decide to calculate the period of vibration from the Rayleigh method, many codes apply an upper bound to the period of vibration from the Rayleigh method. This is another procedure which is used to safeguard against unrealistically high periods of vibration used in the design to lower the base shear forces [30].

The seismic zone considered in this study is zone 1 and the shape of spectrum is type 1 as per the Egyptian zoning system with design ground acceleration, $a_{g}$ of $0.1 \mathrm{~g}$ associated with the code reference probability of exceedance of $10 \%$ in 50 yrs as shown in Fig. 1. The two models are considered as a residential buildings with importance factor $\gamma=1$. The soil class is considered "C" and a soil factor $S=1.5$. The reduction factor, $R$, is taken considering the vertical loads and the total base shear are totally resisted by the frame structure without using shear walls or bracings $(\mathrm{R}=5)$. It should be noted that, ECP-201 [10] recommends that in the application of the Equivalent Static load Method "ESL", the building should meet the criteria for regularity in both plan and elevation, and with calculated structural period $\mathrm{T}$ not greater than $2 \mathrm{sec}$ or $4 T_{c}$ ( $1 \mathrm{sec}$ for the selected soil class "C"). In ESL method, according to the ECP-201 [10], a total seismic mass including selfweight and floor cover plus $25 \%$ of live load is considered. The base shear is determined as a percentage of the total building weight that gives a value of $2.58 \%$ of the total weight of the building in 6-story building and $1.82 \%$ in 12 -story building.

\subsection{Nonlinear time history (TH) method}

Nonlinear time-history analysis is by far the most comprehensive method for seismic analysis. The earthquake record in the form of acceleration time history is input at the base of the structure [33]. The response of the structure is computed at each second for the entire duration of an earthquake. This method differs from response spectrum analysis because the effect of "time" is considered. That is, stresses and deformations in the structure at an instant are considered as an initial boundary condition for computation of stresses in the next step. Furthermore, nonlinearities that commonly occur during an earthquake can be included in the time-history analysis. Such nonlinearities cannot be easily incorporated in response spectrum analysis. Unlike the response spectrum method, nonlinear time-history analysis does not assume a specific method for mode combination. 
Hence, results are realistic and not conservative. Furthermore, this method is equivalent to getting 100\% mass participation using response spectrum analysis. Full mass participation is necessary to generate correct earthquake forces. Usually, only $90-95 \%$ participation is obtained in response spectrum analysis. All types of nonlinearities can be accounted for in this analysis. This could be very important when seismic retrofit involves energy dissipation using yielding of members or plastic hinge rotation. However, this method is very expensive and time consuming to perform. Large amounts of information are generated. Furthermore, input earthquake is never known with certainty. Hence, three to five different histories should be used, further increasing the cost. The equation of motion for a system subjected to earthquake excitations can be written as [34],

$[\mathrm{M}] \ddot{u}+[\mathrm{C}] \dot{u}+[\mathrm{K}] u=\mathrm{F}(\mathrm{t})$

In which, $\mathrm{M}, \mathrm{C}$ and $\mathrm{K}$ are the mass; damping and stiffness matrices, respectively. $\mathrm{F}(\mathrm{t})$ is the seismic excitation and $\ddot{u}, \dot{u}$ and $u$ are accelerations, velocities and displacements time-dependent vectors, respectively. Since the results of the time history depends mainly on the characteristic of the used acceleration time-history records and the shapes of their corresponding elastic response spectra [31], the reason of using the inelastic TH method is to verify the results obtained by other code specific analysis procedures (ESL and RS methods) against a time-history record. Nonlinear time-history analysis was performed taking into consideration the P- $\Delta$ and large displacements effect. A constant damping ratio of 0.05 has been taken for RC buildings. The inelastic time-history analysis is performed using the direct integration technique considering a time step of 0.005 second. Nonlinear analysis could be used to justify a design that would not satisfy the prescriptive building code requirements. Story drifts and floor accelerations are important indicators of damage to nonstructural components and overall building performance. For nonlinear seismic analyses, a total seismic mass including self-weight and floor cover "Dead Load; $D L$ " plus $25 \%$ of Live Load " $L L "(1.0 D L+0.25 L L)$ is considered according to ECP-201 [10].

\section{Finite element modeling}

\subsection{Target multi-story MRF building description}

During the past two decades, the building environment in Egypt had extensively utilized medium rise R.C. buildings having twelve stories, the maximum height allowed by the local authorities in most districts. These building are built with different configurations and structural systems having varying stiffness parameters that may have great influence on their seismic behavior. Two Samples for typical buildings with six and twelve stories are chosen for this study as shown in Fig. 2, building's layout is essentially bi-symmetric in plan, and regular plans of four equal bays with a typical bay width of $5 \mathrm{~m}$ in both directions, and is representative of benchmark typical buildings in current practice in Egypt. The height of every story (column height) is taken equal to $3 \mathrm{~m}$, as a normal height for residential buildings. Beams are assumed on all grid lines. The building structural elements have been first designed according to Egyptian code of practice (ECP-203 [22], ECP-201[10]) under static loads assuming an un-cracked section for beam and slabs in the analysis. Slab thickness was taken $15 \mathrm{~cm}$ and beam section was taken $30 \times 60 \mathrm{~cm}$. These 


\section{2}

Shehata E Abdel Raheem et al., Soil-structure interaction effects on seismic response of multi....

sections have been checked under seismic actions by using the Egyptian code for load and forces (ECP-201 [10]) to satisfy the Egyptian code requirements taking into consideration the effect of earthquake loads. The minimum safe column cross-section under static and dynamic loads, to satisfy the Egyptian code requirements (ECP-203 [22], ECP-201 [10]), is $0.6 \times 0.6 \mathrm{~m}$ for 6 -story building and $0.8 \times 0.8 \mathrm{~m}$ for 12-story building. The materials used in the design are $\mathrm{C} 250$ for concrete and St52 for steel, the material for the building structure is taken as a reinforced concrete with constant properties of modulus of elasticity $E=2.21 \times 10^{6} \mathrm{t} / \mathrm{m}^{2}$, Poisson's ratio $v=0.2$, density of concrete $=2.5 \mathrm{t} / \mathrm{m}^{3}$, compressive strength $\mathrm{f}_{\mathrm{c}}=2500 \mathrm{t} / \mathrm{m}^{2}$, yield strength $\mathrm{f}_{\mathrm{y}}=36000 \mathrm{t} / \mathrm{m}^{2}$. For gravity load design, dead loads include the self-weight of the structure, a typical floor cover of $0.15 \mathrm{t} / \mathrm{m}^{2}$ and partition (wall) loads intensity of $1 \mathrm{t} / \mathrm{m}^{\prime}$ on all beams including plastering and assuming typical walls thickness of $0.25 \mathrm{~m}$. The model is assumed to be a residential building with live load $=0.2 \mathrm{t} / \mathrm{m}^{2}$.

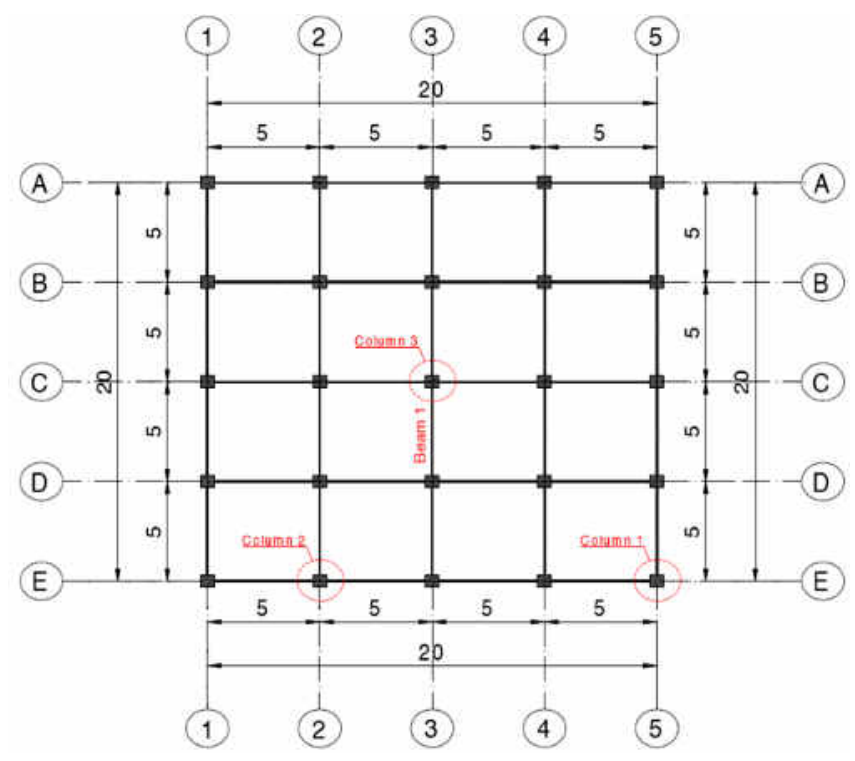

a) Plan configuration
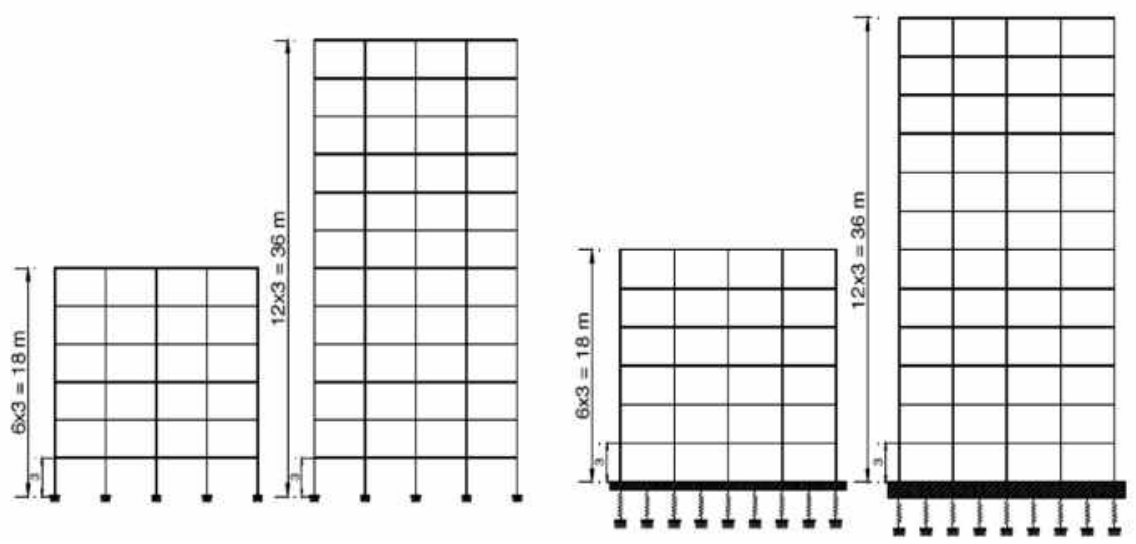

b) Fixed base model "NSSI model"

c) Soil Structure Interaction model "SSI model"

Fig. 2. Schematic of 6-story and 12-story buildings' models 


\subsection{Raft foundation and underneath soil conditions}

For understanding the importance of the effect of soil structure interaction on the seismic response of multi-story buildings, this study's attention focuses on evaluating the seismic response of reinforced concrete multi-story buildings on raft foundation with thickness equal to $0.6 \mathrm{~m}$ for 6 -story building and $1.0 \mathrm{~m}$ for 12 -story building. The underneath soil is modeled by Winkler spring approach with equivalent static stiffness based on soil modulus of elasticity of range from 24480, 12240 and $6120 \mathrm{t} / \mathrm{m}^{2}$ for stiff, medium and soft soil [35]. The soil spring stiffness can be given as [36-38].

$$
\begin{aligned}
& K_{z}=\frac{G l}{1-v}\left[0.73+1.54\left(\frac{B}{L}\right)^{0.75}\right] \\
& K_{y}=\frac{G L}{2-v}\left[2+2.5\left(\frac{B}{L}\right)^{0.85}\right] \\
& K_{x}=K_{y}-\frac{0.2}{0.75-v} G L\left(1-\frac{B}{L}\right) \\
& G=\frac{E}{2(1+v)}
\end{aligned}
$$

Where, $G$ is the shear modulus of soil, $E$ is the modulus of elasticity of soil; $v$ is the Poisson's ratio of soil. $L$ and $B$ are the length and width of foundation, respectively. The elastic properties and stiffness of soil spring for stiff, medium and soft soil are tabulated in Table 1.

\section{Table 1.}

Elastic Properties and stiffness of soil area spring.

\begin{tabular}{|l|c|c|c|c|c|}
\hline $\begin{array}{c}\text { Soil } \\
\text { condition }\end{array}$ & $\begin{array}{c}\text { Poisson's } \\
\text { ratio } v\end{array}$ & $\begin{array}{c}\text { Modulus of } \\
\text { elasticity } E\left(t / m^{2}\right)\end{array}$ & $\begin{array}{c}K_{x} \\
\left(t / m^{2} / m^{\prime}\right)\end{array}$ & $\begin{array}{c}K_{y} \\
\left(t / m^{2} / m^{\prime}\right)\end{array}$ & $\begin{array}{c}K_{z} \\
\left(t / m^{2} / m^{\prime}\right)\end{array}$ \\
\hline Stiff soil & 0.33 & 24480 & 1127.21 & 1127.21 & 1417.29 \\
\hline Medium soil & 0.33 & 12240 & 563.6 & 563.6 & 708.64 \\
\hline Soft soil & 0.33 & 6120 & 281.8 & 281.8 & 354.32 \\
\hline
\end{tabular}

\subsection{Finite element modeling}

A three-dimensional mathematical model of the physical structure will be used that represents the spatial distribution of the mass and stiffness of the structure to an extent that is adequate for the calculation of the significant features of the building's dynamic response. All structures are modeled and analyzed in this paper using ETABS 9.7 [39-43]. The building is modeled as 3D frame structure using frame elements for columns, longitudinal beams and transverse beams, shell element for slabs and raft and spring elements for soil as shown in Fig. 2.

\subsection{Input seismic excitation}

It is impossible to predict ground motion characteristics that may occur in the future at a construction site because the property of the ground motion is interrelated to many factors such as fault mechanism, seismic wave propagation from source to site and the amplification characteristics of ground. The important factors of ground motions affecting 
Shehata E Abdel Raheem et al., Soil-structure interaction effects on seismic response of multi....

the structure's response results are peak ground acceleration, frequency contents, duration of ground motion and shapes of waveform. Egypt is a region of moderate seismicity, where infrequent moderate to severe earthquakes have occurred in the past. However, there is a serious lack of strong motion records of engineering interest in the region. Therefore, the use of a large number of artificial or natural earthquake records from the literature is indispensible for the nonlinear time history analysis. The seismic design guidelines provide an acceleration response spectrum for estimating the design seismic force of a structure. Accordingly, the input ground motion applied to the dynamic response analysis of structures would be appropriate for the ground motion history which is highly related with design seismic force. A suite of nine-ground motion records from seven different earthquakes [44] is selected for the purpose of understanding the input ground motion effect, as listed in Table 2.

Table 2.

Characteristics of earthquake ground motion records used in the analysis.

\begin{tabular}{|c|c|c|c|c|c|c|c|c|c|}
\hline d & $\begin{array}{c}\text { PGA } \\
(\mathrm{g})\end{array}$ & $\begin{array}{l}\text { Input } \\
\text { wave }\end{array}$ & $M_{w}$ & Earthquake / Station & $\begin{array}{l}\text { Scale } \\
\text { factor }\end{array}$ & $\begin{array}{l}\text { EPD } \\
(\mathrm{km})\end{array}$ & $\begin{array}{l}\mathrm{PGV} \\
(\mathrm{cm} / \mathrm{s})\end{array}$ & $\begin{array}{l}\text { PGD } \\
(\mathrm{cm})\end{array}$ & $\begin{array}{l}T_{g} \\
(\mathrm{~s})\end{array}$ \\
\hline \multirow{3}{*}{ ב } & 0.21 & $1 \mathrm{MVH}$ & 6.0 & $\begin{array}{l}\text { N. Palm Springs, } 1986 \text { / } \\
\text { Morongo Valley }\end{array}$ & 1.5 & 10.1 & 40.9 & 15.0 & 1.90 \\
\hline & 0.30 & $\begin{array}{l}\text { 2A- } \\
\text { GRN }\end{array}$ & 6.0 & $\begin{array}{l}\text { Whittier narrows, } 1987 \text { / } \\
\text { E-Grand Ave }\end{array}$ & 1.7 & 9.0 & 23.0 & 3.3 & 0.70 \\
\hline & 0.29 & 3G06 & 6.2 & $\begin{array}{l}\text { Morgan Hill, } 1994 \text { / } \\
\text { Gilroy Array \#6 }\end{array}$ & 1.0 & 11.8 & 36.7 & 6.1 & 1.20 \\
\hline \multirow{3}{*}{$\begin{array}{l}\frac{0}{\pi} \\
\frac{\pi}{0} \\
\frac{0}{0} \\
\sum\end{array}$} & 0.48 & $4 \mathrm{CYC}$ & 6.9 & $\begin{array}{l}\text { Loma Prieta, } 1989 \text { / } \\
\text { Coyote Lake Dam }\end{array}$ & 1.2 & 21.8 & 39.7 & 15.2 & 0.65 \\
\hline & 0.51 & 5STG & 6.9 & $\begin{array}{l}\text { Loma Prieta, } 1989 \text { / } \\
\text { Saratoga-Aloha Ave }\end{array}$ & 1.0 & 11.7 & 41.2 & 16.2 & 1.80 \\
\hline & 0.59 & 6NPS & 6.0 & $\begin{array}{l}\text { N. Palm Springs, } 1986 / \\
5070\end{array}$ & 0.7 & 8.2 & 73.3 & 11.5 & 1.10 \\
\hline \multirow{3}{*}{.05 } & 0.60 & $\begin{array}{l}\text { 7D- } \\
\text { PVY }\end{array}$ & 5.8 & $\begin{array}{l}\text { Coalinga, } 1983 \text { / Pleasant } \\
\text { Valley P.P. }\end{array}$ & 1.7 & 17.4 & 34.8 & 8.1 & 0.65 \\
\hline & 0.84 & 8RRS & 6.7 & Northridge, 1994 / Rinaldi & 0.6 & 7.1 & 166.1 & 28.8 & 1.05 \\
\hline & 1.04 & 9СРM & 7.1 & $\begin{array}{l}\text { Cape Mendocino, } 1992 \text { / } \\
\text { Cape Mendono }\end{array}$ & 0.6 & 8.5 & 42.0 & 12.4 & 2.00 \\
\hline
\end{tabular}

\section{Numerical results and discussions}

This study aims to quantify the effect of Soil-Structure Interaction and foundation flexibility on the structural response demands of MRF buildings so that designers can be aware of the likely impact of their decisions and to evaluate Egyptian code seismic provisions for seismic loads and analysis methods during the seismic design of buildings and recommend alternative solutions for cases wherein existing provisions do not lead to satisfactory results and. Time History analysis $(\mathrm{TH})$ using a set of time history records has been performed to evaluate the Equivalent Static Load (ESL) and the Response Spectrum (RS) analysis methods. A parametric study is carried out to evaluate the design parameter effects on the building seismic demands including the fundamental period, total base shear, displacements, story drifts, moments at beam ends and inner force of column. The design 
parameters include the supporting soil conditions (three types of soil range from soft, medium, stiff soil conditions); number of stories (6- and 12-story buildings); raft foundation flexibility and different boundary conditions at foundation level (fixed base "NSSI" model and SSI Model). A constant beam, slab, column cross-sections with rigid diaphragm assumption are considered in the analysis with different soil spring stiffness (soil different modulus of elasticity) as given in Table 3. In order to study the soil-structure interaction, fundamental period, base shear, displacement and story drift moments at beam ends, as well as inner force of column in the two models are compared. For convenience, response ratio is defined as follows: Response ratio = (peak response of structure in Soil Structure Interaction model) / (peak response of structure in Fixed base model).

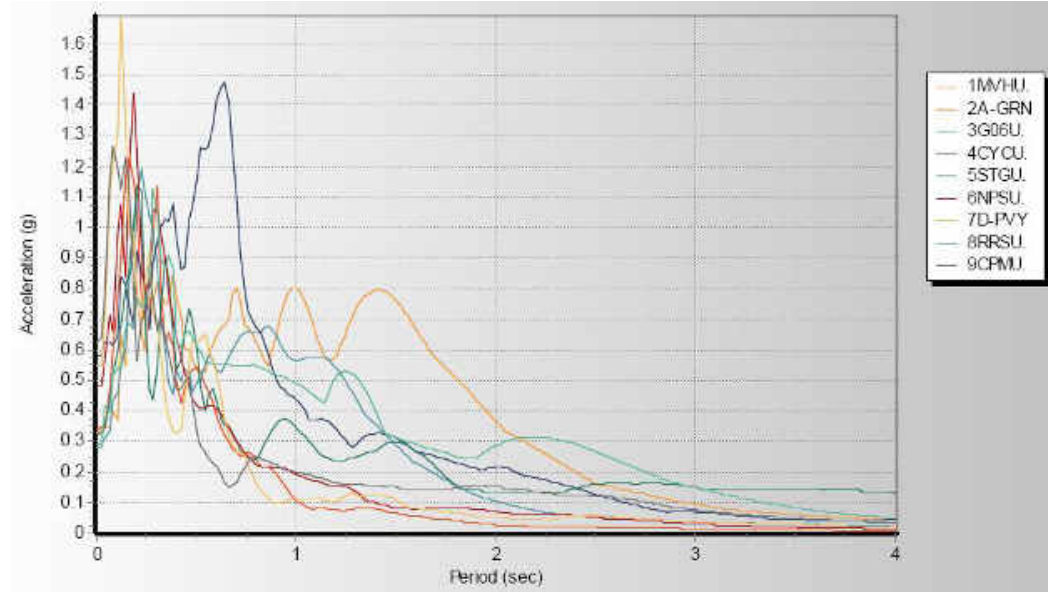

Fig. 3. 5\%-damped response spectrum for nine records

\subsection{Natural vibration analysis}

The period of vibration is a fundamental parameter in the force-based design of structures as this parameter defines the spectral acceleration and thus the base shear force to which the building should be designed. This study takes a critical look at the way in which seismic design codes around the world have allowed the designer to estimate the period of vibration for use in both linear static and dynamic analysis. In most building design projects, empirical building period formulas are used to initiate the design process [45]. The fundamental period of vibration, $T$, is a function of the stiffness of the lateral load resisting system and the building mass. The fundamental period in ECP-201 [10], $T$, is not influenced by the change of SSI but depends only on the building height. Table 4 presents different fundamental periods, for the studied buildings as obtained from the structural analysis using finite element models and empirical expression in the ECP-201 [10] and other international building codes. In both 6story and 12-story buildings, the computed periods from empirical expressions are significantly shorter than those computed from structural models especially for building structures with soft soil-spring-stiffness. As the buildings soil-spring-stiffness decrease; the fundamental period increases. 
Shehata E Abdel Raheem et al., Soil-structure interaction effects on seismic response of multi....

Table 3.

Building structural element dimensions for different type of soil

\begin{tabular}{|c|c|c|c|c|c|c|}
\hline \multicolumn{2}{|c|}{ Model } & $\begin{array}{c}\text { Beam } \\
\text { size }(\mathrm{cm})\end{array}$ & $\begin{array}{l}\text { Slab thickness } \\
(\mathrm{cm})\end{array}$ & $\begin{array}{l}\text { Column } \\
\quad(\mathrm{cm})\end{array}$ & $\begin{array}{c}\text { Raft } \\
\text { thickness }\end{array}$ & $\begin{array}{l}\text { Soil modulus of } \\
\text { elasticity }\left(t / \mathrm{m}^{2}\right)\end{array}$ \\
\hline \multirow{4}{*}{$\begin{array}{l}\vec{d} \\
\text { की } \\
\text { bे }\end{array}$} & NSSI-1 & \multirow{4}{*}{$25 \times 60$} & \multirow{4}{*}{15} & \multirow{4}{*}{$60 \times 60$} & Fixed base & N.A \\
\hline & SSI-1 & & & & 60 & 24480 \\
\hline & SSI-2 & & & & 60 & 12240 \\
\hline & SSI-3 & & & & 60 & 6120 \\
\hline \multirow{4}{*}{ 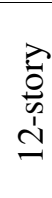 } & NSSI-2 & \multirow{4}{*}{$25 \times 60$} & \multirow{4}{*}{15} & \multirow{4}{*}{$80 \times 80$} & Fixed base & N.A \\
\hline & SSI-4 & & & & 100 & 24480 \\
\hline & SSI-5 & & & & 100 & 12240 \\
\hline & SSI-6 & & & & 100 & 6120 \\
\hline
\end{tabular}

\section{Table 4.}

Fundamental period of the RC moment resisting frame buildings' models

\begin{tabular}{|c|c|c|c|c|c|c|c|c|c|}
\hline \multirow{2}{*}{ Code } & \multirow{2}{*}{ Period, $T$} & \multicolumn{8}{|c|}{ Fundamental Period (sec) } \\
\hline & & NSSI1 & SSI1 & SSI2 & SSI3 & NSSI2 & SSI4 & SSI5 & SSI6 \\
\hline \multicolumn{2}{|c|}{ 3D model natural vibration analysis } & 0.98 & 1.07 & 1.12 & 1.21 & 1.92 & 2.15 & 2.32 & 2.60 \\
\hline \multicolumn{2}{|c|}{ Fundamental period response ratio } & ---- & 1.09 & 1.14 & 1.23 & $\begin{array}{ll}--- \\
--\end{array}$ & 1.12 & 1.21 & 1.36 \\
\hline ECP-201 (2008) & $T=0.075 H^{3 / 4}$ & \multicolumn{4}{|c|}{0.66} & \multicolumn{4}{|c|}{1.10} \\
\hline ECP-201 (1993) & $T=0.1 \mathrm{~N}$ & \multicolumn{4}{|c|}{0.61} & \multicolumn{4}{|c|}{1.20} \\
\hline IBC (2003) & $T=0.073 H^{3 / 4}$ & \multicolumn{4}{|c|}{0.65} & \multicolumn{4}{|c|}{1.08} \\
\hline UBC (1997) & $T=0.049 H^{3 / 4}$ & \multicolumn{4}{|c|}{0.43} & \multicolumn{4}{|c|}{0.71} \\
\hline EC8 (2004) & $T=0.075 H^{3 / 4}$ & \multicolumn{4}{|c|}{0.66} & \multicolumn{4}{|c|}{1.10} \\
\hline NBCC (2005) & $T=0.05 H^{3 / 4}$ & \multicolumn{4}{|c|}{0.44} & \multicolumn{4}{|c|}{0.74} \\
\hline
\end{tabular}

Note: $H$ is the building height above the foundation level and $N$ is the number of the stories.

Table 4 show the disparity between the fundamental period of vibration from empirical period-height equation from different codes and the period of vibration from Eigen value or Rayleigh analysis of a bare frame model. The fundamental period estimated by ECP-201 empirical equation is underestimated especially for flexible models; the fundamental period reaches $183 \%$ and 236\% in models SSI3 and SSI6, respectively. Many codes recognize that the period of vibration from the simplified period-height equation is more realistic, having been directly obtained from the measured periods of vibration of buildings subject to earthquake ground motions, but that when higher modes are important (in tall and/or irregular structures) the modal response spectrum method gives a more realistic profile of the lateral forces [5]. However, the empirical equation should be calibrated to obtain a conservative estimate of the base shear. As the buildings soil stiffness decrease; fundamental period response ratio increases, fundamental period response ratio is higher than 1.0, range from 1.09 to 1.23 for 6story model and from 1.12 to 1.36 for 12-story model, as shown in Table 4.

\subsection{Seismic response analysis}

\subsubsection{Story drift ratio response}

Story drift ratio is the maximum relative displacement of each floor divided by the height of the same floor is an important parameter that has been evaluated. The story drift 
JES, Assiut University, Faculty of Engineering, Vol. 42, No. 4, July 2014, pp. 905 - 930

ratio response demand is investigated for studied multi-story building of 6- and 12-story buildings using different analyses, the story drift ratio over the building's height for different soil condition range from stiff, medium to soft soils along with ratio of the response of the SSI model to that of fixed base model are introduced in Figs. 4 and 5 for 6-story building and Figs. 6 and 7 for 12-story building. The seismic response demands are calculated using ESL; RS and average envelope of TH of the nine records.

Figs. 4 (a, b, c, d) show that story drift ratio distribution of 6-story model increases gradually and reaches its maximum value in the $2^{\text {nd }}$ story level. The maximum values in NSSI-1, SSI-1, SSI-2 and SSI-3 using equivalent static load (ESL) method are 0.00081, $0.00089,0.00094$ and 0.00102 , respectively, and using response spectra (RS) method are $0.00055,0.00086,0.00089$ and 0.00095 , respectively and the average value of using time history (TH) method of nine earthquake ground motion records are 0.00115, 0.00122, 0.00122 and 0.0013 , respectively. As the soil stiffness decreases, the story drift ratio increases. The story drift values calculated by TH method have higher values than ESL and RS methods, while those obtained by RS have lower values for story drift.

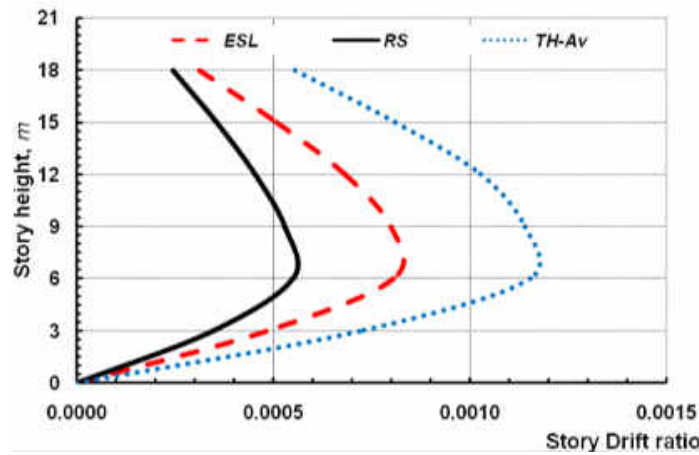

a) NSSI-1

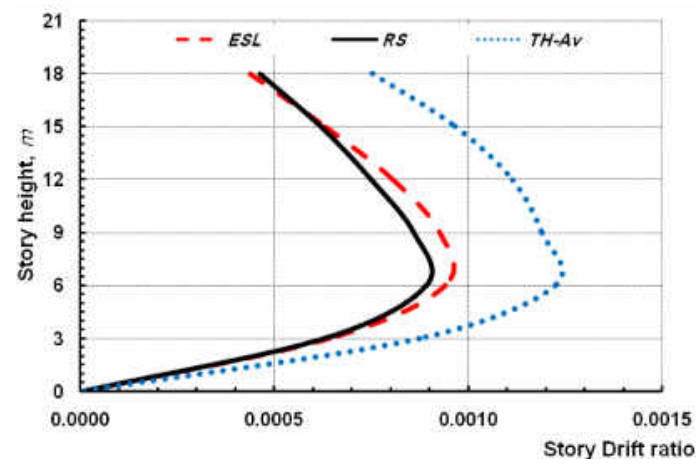

c) SSI-2

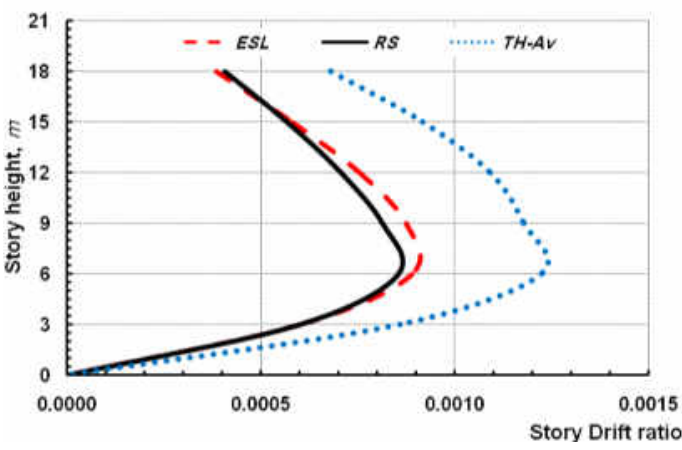

b) SSI-1

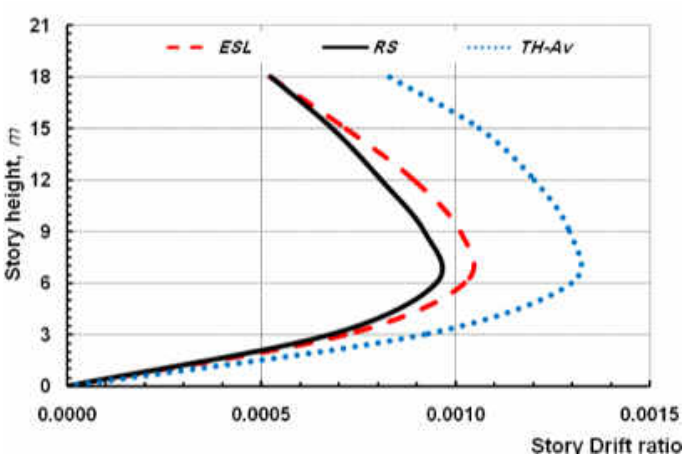

d) SSI-3

Fig. 4 Story drift ratio of 6-story building

Figs. 5 (a, b, c) show that story drift ratio response distribution over building height compared to that response value of fixed based model for 6-story model. The story drift ratio increases over the building height as the supporting soil change from stiff to soft 
condition. This increase trend is more significant in the upper and lower stories. The maximum response ratio of SSI-1, SSI-2 and SSI-3 compared to that of fixed base using equivalent static load (SL) method are 1.24, 1.39 and 1.66, respectively, and using response spectra method (RS) are 1.74, 1.89 and 2.14, respectively and the average value of using time history method $(\mathrm{Av}-\mathrm{TH})$ of nine earthquake ground motion records are 1.22, 1.35 and 1.49 , respectively. As the soil stiffness decrease, the story drifts ratio response ratio increase. Lower and upper stories are more affected with SSI than middle stories. As the raft foundation underneath soil flexibly causes the increase of story drift ratio. The greatest story drift ratio increase occurs for the structures located on the soft soil

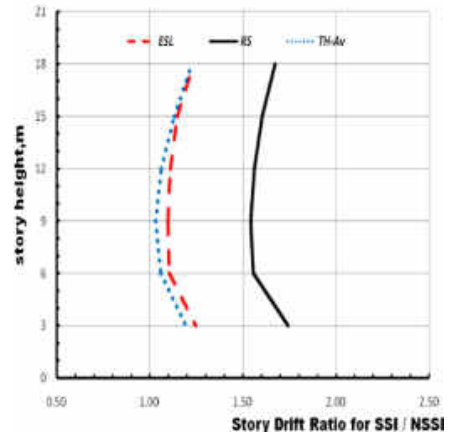

a) SSI-1

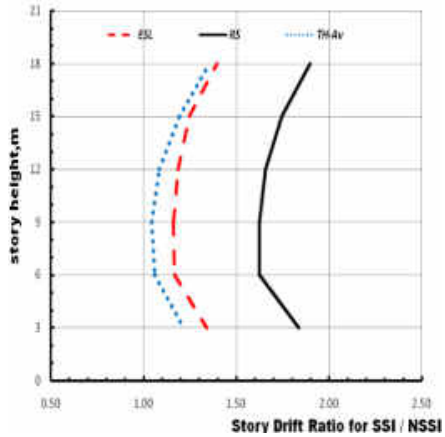

SSI-2

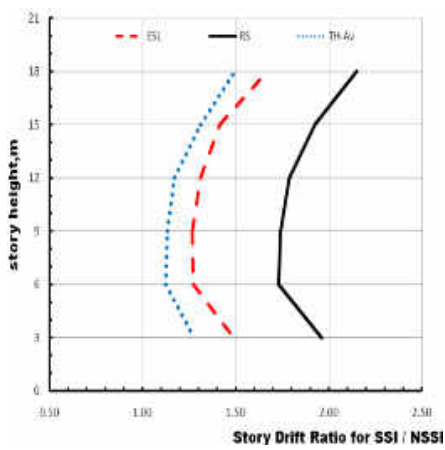

c) SSI-3

Fig. 5. Story drift ratio of SSI reference to NSSI models of 6-story building

Figs. 6 (a, b, c, d) show that story drift ratio distribution of 12-story model increases gradually and reaches its maximum value in the $3^{\text {rd }}$ and $4^{\text {th }}$ story levels. The maximum values in NSSI-2, SSI-4, SSI-5 and SSI-6 using equivalent static load (ESL) method are $0.00115,0.00134,0.0015$ and 0.00176 , respectively, and using response spectra (RS) method are $0.00104,0.00172,0.00189$ and 0.00218 , respectively and the average value of using time history $(\mathrm{TH})$ method of nine earthquake ground motion records are 0.00106 , $0.00111,0.00115$ and 0.00117 respectively. As the soil stiffness decreases; the story drift ratio increases. The story drift values calculated by $\mathrm{TH}$ method have higher values than ESL and RS methods, while those obtained by RS have lower values for story drift.

Figs. 7 (a, b, c) show that story drift ratio response distribution over building height compared to that response value of fixed based model for 12-story model. The story drift ratio increases over the building height as the as the supporting soil change from stiff to soft condition, this increase trend is more significant in the upper and lower stories. The maximum response ratio of SSI-4, SSI-5 and SSI-6 compared to that of fixed base using equivalent static load (SL) method are 1.59, 2.06 and 2.89, respectively, and using response spectra method (RS) are 2.09, 2.65 and 3.68, respectively and the average value of using time history method (TH- Av) of nine earthquake ground motion records are 1.4, 1.56 and 1.76, respectively. As the soil stiffness decrease, the story drifts ratio response ratio increase. Lower and upper stories are more affected with SSI than middle stories. As the raft foundation underneath soil flexibly causes the increase of story drift ratio. The greatest story drift ratio increase occurs for the structures located on the soft soil, the SSI gets more significant effect on the story drift ratio as the number of story increases. 
JES, Assiut University, Faculty of Engineering, Vol. 42, No. 4, July 2014, pp. 905 - 930

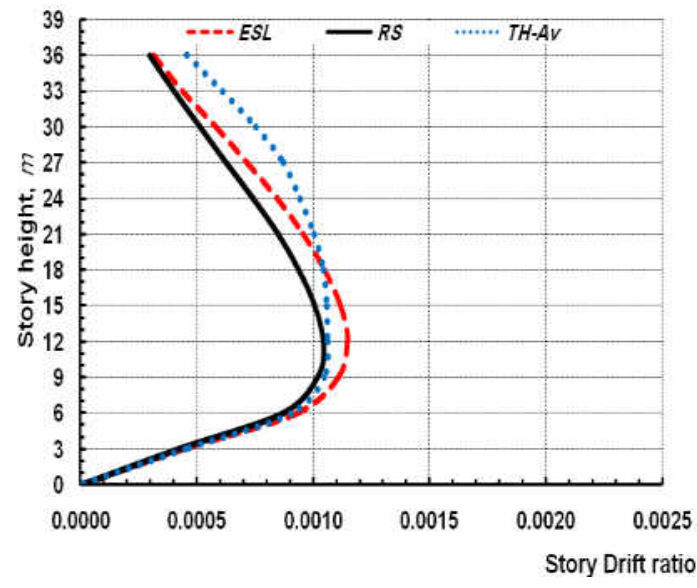

a) NSSI-2

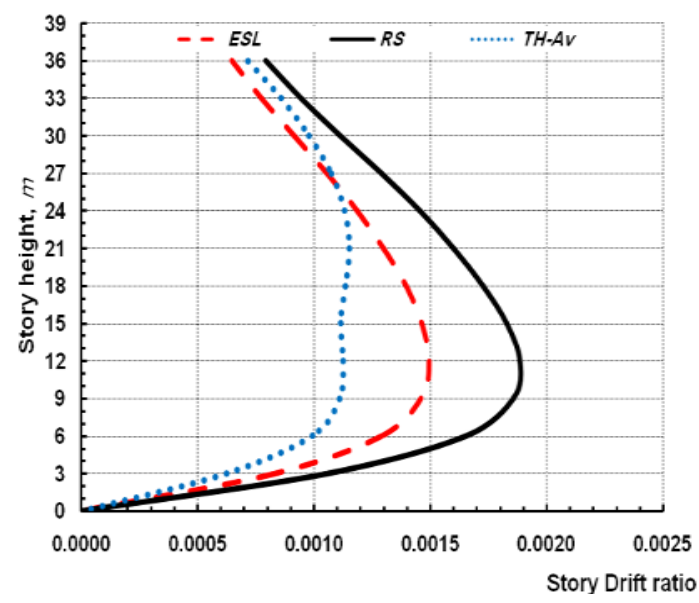

c) SSI-5

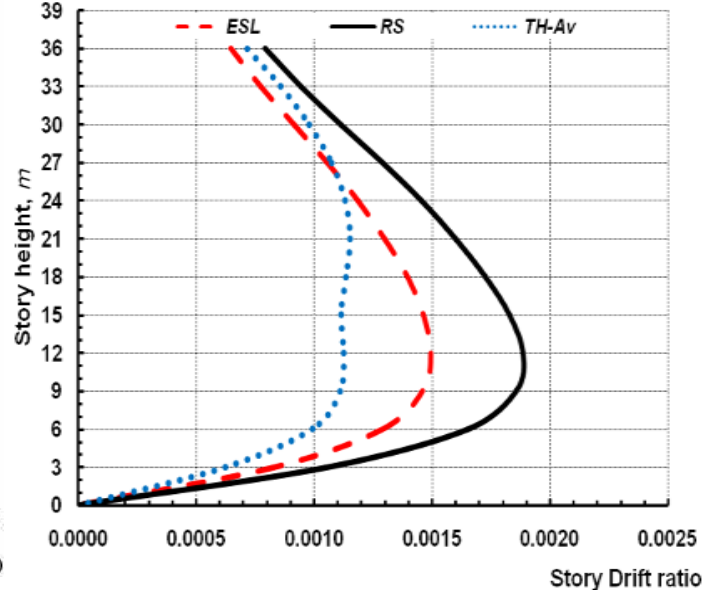

b) SSI-4

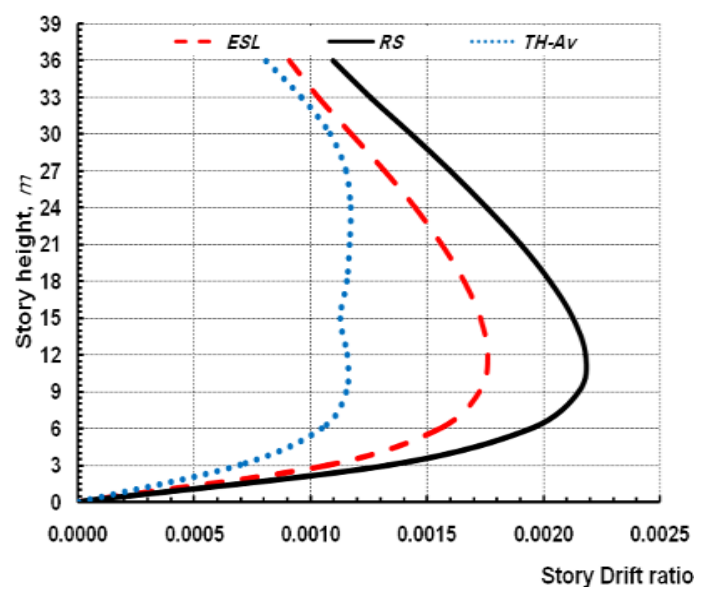

d) SSI-6

Fig. 6. Story drift ratio of 12-story building

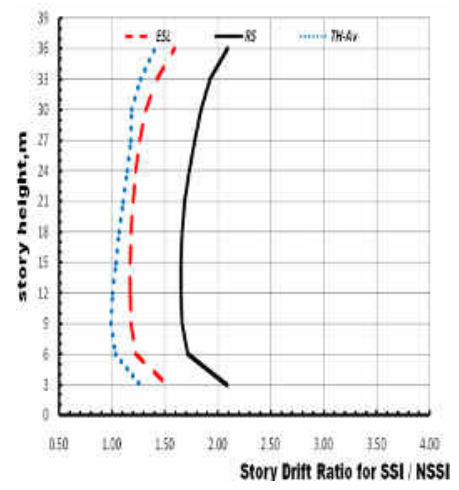

a) SSI-4

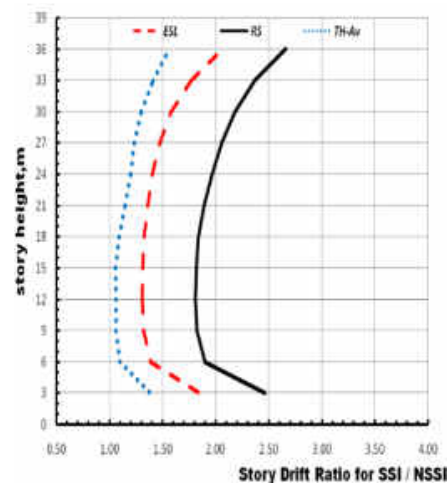

b) SSI-5

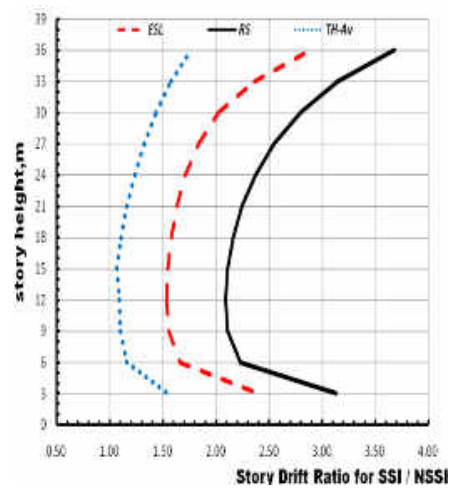

c) SSI-6

Fig. 7. Story drift ratio of SSI reference to NSSI models of 12-story building 


\subsubsection{Story lateral displacement response}

Soil-structure interaction particularly for MRF buildings resting on relatively soft soils may significantly amplify the lateral displacements and inter-storey drifts. This amplification of lateral deformations may change the performance level of the building frames. Thus, a comprehensive dynamic analysis to evaluate the realistic performance level of a structure should consider the effects of SSI in the model. In this study, an enhanced numerical soilstructure model has been developed which treats the behavior of soil and structure with equal rigor. In this study, the effect of SSI on the story lateral displacement of 6-story and 12-story buildings has been studied using three different analysis methods, the lateral displacement profile are presented in Figs. 8 - 11. It is observed that the displacement increase occurs in SSI models, the displacement increases more in foundations located on soft soil and this value decreases with increasing soil rigidity.

Figs. 8 (a, b, c, d) show that story displacement profile over building height of 6-story increases nonlinearly with the structural height. The maximum displacements reach for NSSI1, SSI-1, SSI-2 and SSI-3 models using equivalent static load method are 9.8, 11.5, 12.6 and $14.5 \mathrm{~mm}$, respectively, and using response spectra method reach 5.9, 9.5, 10.6 and $12.4 \mathrm{~mm}$, respectively and using $\mathrm{TH}$, the average value of nine earthquake records reaches $14.11,15.62$, 15.8 and $18.1 \mathrm{~mm}$ respectively. As the soil stiffness decreases, the story displacement increases, Story displacement from TH analysis is higher than ESL and RS analysis.

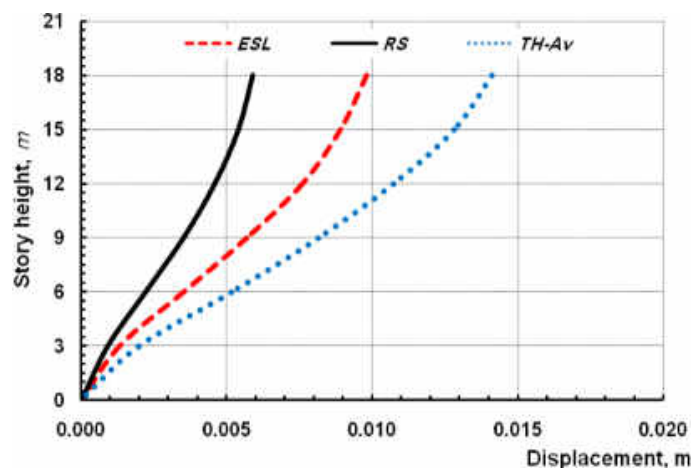

a) NSSI-1

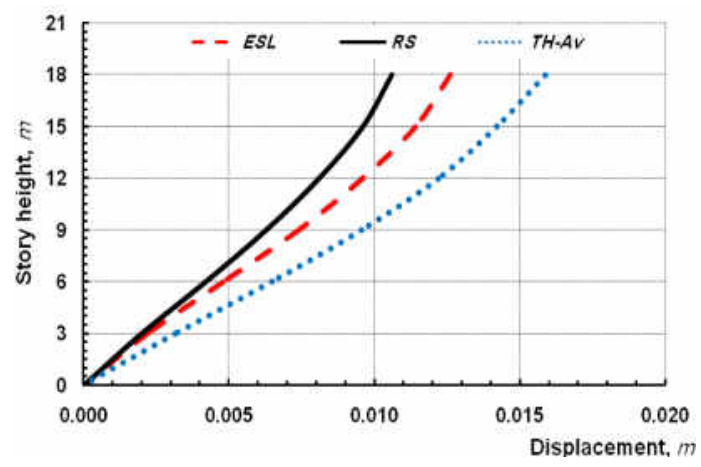

c) SSI-2

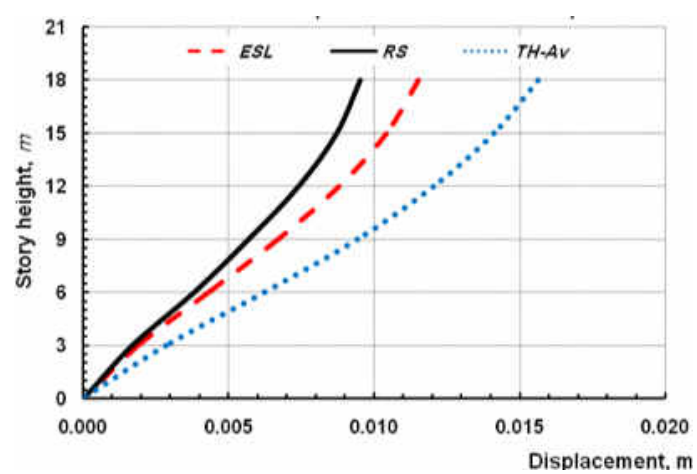

b) SSI-1

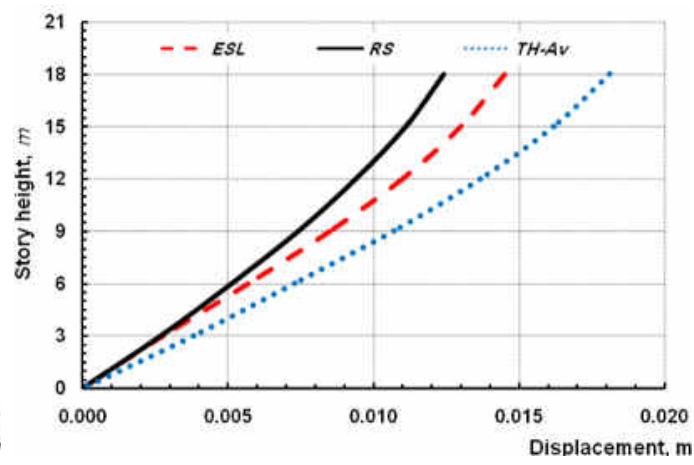

d) SSI-3

Fig. 8. Story lateral displacement responses of 6-story building 
Figs. 9 (a, b, c) show that story displacement response ratio distributions of 6-story SSI models uniformly increase over all stories, the rate of increase become higher for the $1^{\text {st }}$ and $2^{\text {nd }}$ stories. The maximum response ratio of SSI-1, SSI-2 and SSI- 3 using equivalent static load method are 1.46, 1.69 and 2.15, respectively, using response spectra method are $1.88,2.22$ and 3.0 respectively and the average value of using time history method of nine earthquake ground motion records are 1.42, 1.59 and 1.92 respectively. Lower stories are more affected with SSI than the rest stories.

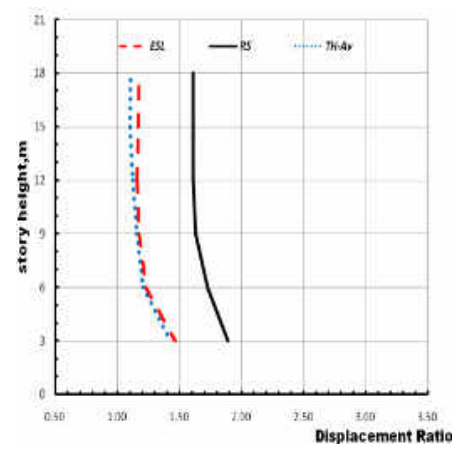

a) SSI-1

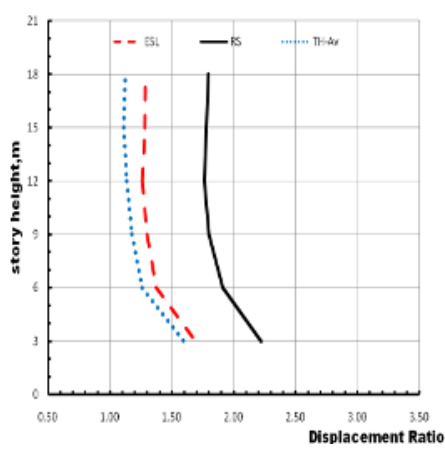

b) SSI-2

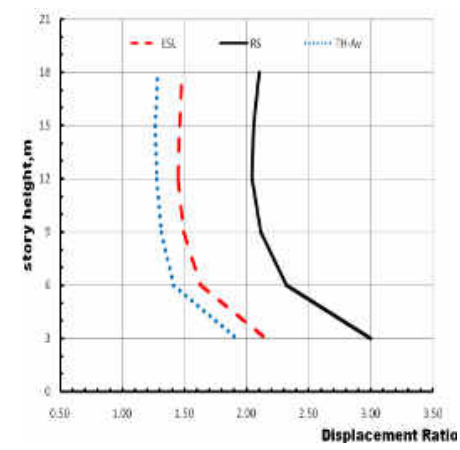

c) SSI-3

Fig. 9. Displacement ratio of SSI reference to NSSI models of 6-story building

Fig. 10 (a, b, c, d) show that story displacement profile over building height of 12-story increases nonlinearly with the structural height. The maximum displacements reach for NSSI-2, SSI-4, SSI-5 and SSI-6 models using equivalent static load method are 26.5, 33.9, 39.6 and $49.6 \mathrm{~mm}$ respectively, using response spectra method reach 21.6, 39.4, 46.3 and $58.5 \mathrm{~mm}$ respectively and using time history method the average value of nine earthquake records reach 26.1, 27.5, 28.0 and $30.7 \mathrm{~mm}$ respectively. As the soil stiffness decreases, the story displacement increases.

Figs. $11(\mathbf{a}, \mathbf{b}, \mathbf{c})$ show that story displacement response ratio distributions of 12 -story SSI models uniformly increase over all stories, the rate of increase become higher for the $1^{\text {st }}$ and $2^{\text {nd }}$ stories. The maximum response ratio of SSI-4, SSI-5 and SSI- 6 using equivalent static load method are 1.83, 2.5 and 3.7, respectively, and using response spectra method are 2.7, 3.7 and 5.4, respectively and the average value of using time history method of nine earthquake ground motion records are 1.47, 2.0 and 2.74, respectively. Lower stories are more affected considering the SSI than the other stories. Soil-structure interaction; particularly for MRF buildings with raft foundation resting on relatively soft soils, create large lateral displacements and inter-storey drifts which may change the performance level of the buildings. 
Shehata E Abdel Raheem et al., Soil-structure interaction effects on seismic response of multi....

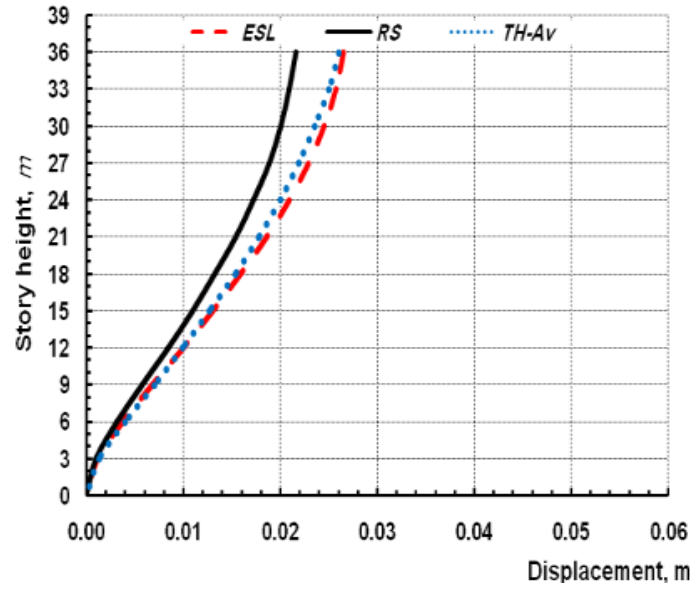

a) NSSI-2

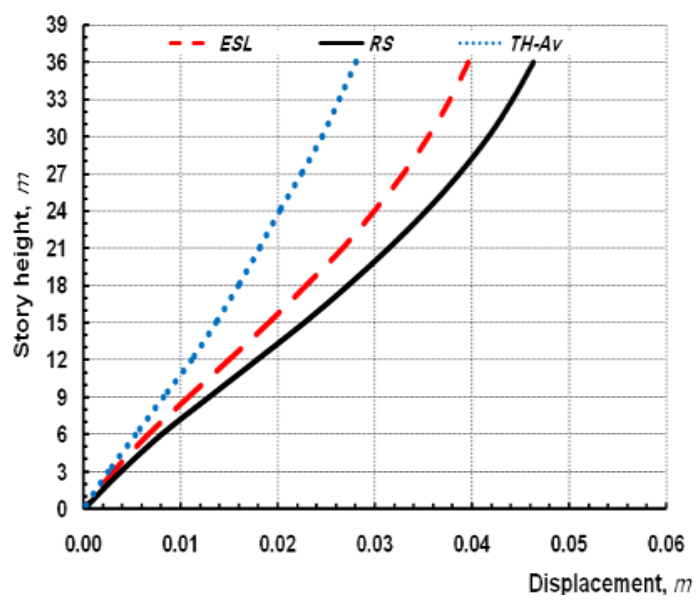

c) SSI-5

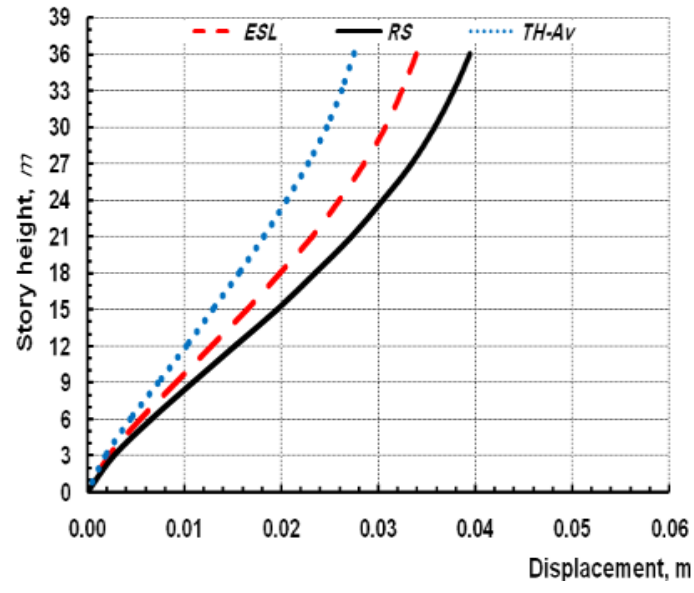

b) SSI-4

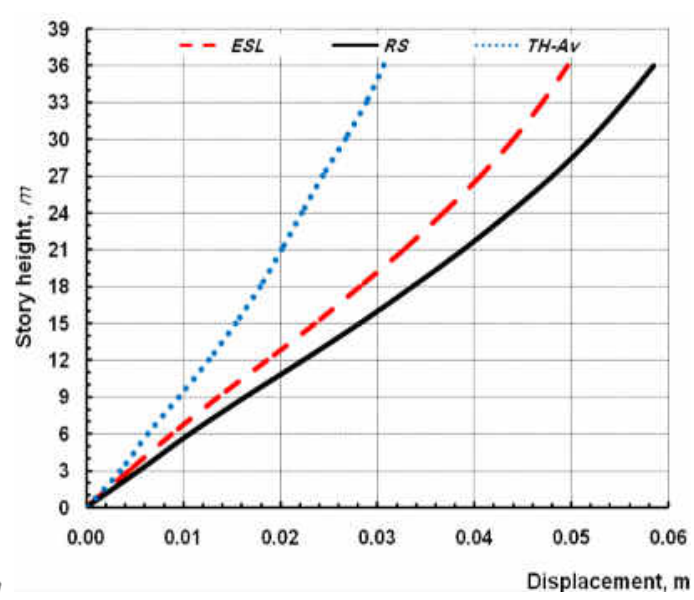

d) SSI-6

Fig. 10. Story lateral displacement responses of 12-story building

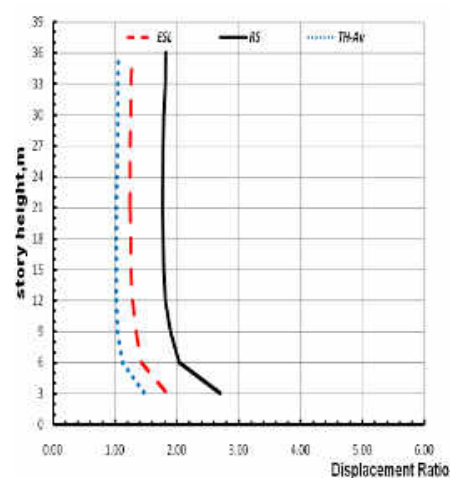

a) SSI-4

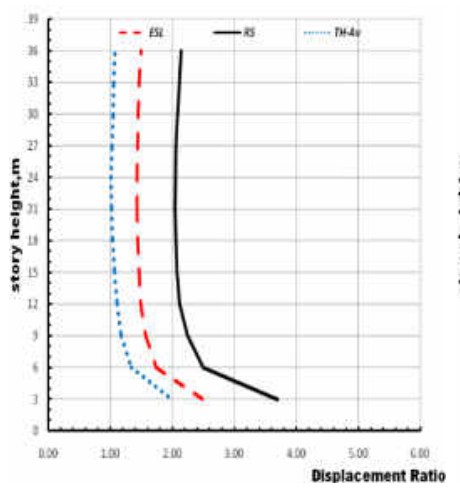

b) SSI-5

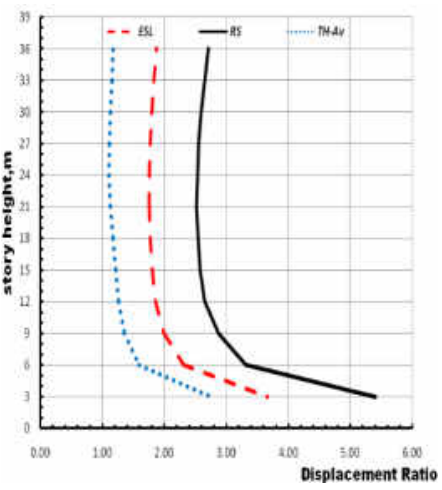

c) SSI-6

Fig. 11. Displacement ratio of SSI reference to NSSI model of 12-story building 


\subsubsection{Story shear force response}

This investigation is aimed to better understand the seismic performance of a typical MRF buildings incorporating soil-structure effect. The seismic response of the structure in terms of the story shear as well as, internal forces over the height of the structural elements are selected as response parameters of interest as these are generally considered the most important response parameters in seismic design practice. The effect of SSI on the story shear response profile over height for 6- and 12-story buildings has been calculated using the three different analysis methods and compared to those obtained from fixed base model. The effect of variation of change in story shear due to the incorporation of soil-flexibility as compared to the same obtained for fixed-base condition expressed as a ratio of such response of SSI models to that of fixed based model has been plotted in Figs. 12 - 15.

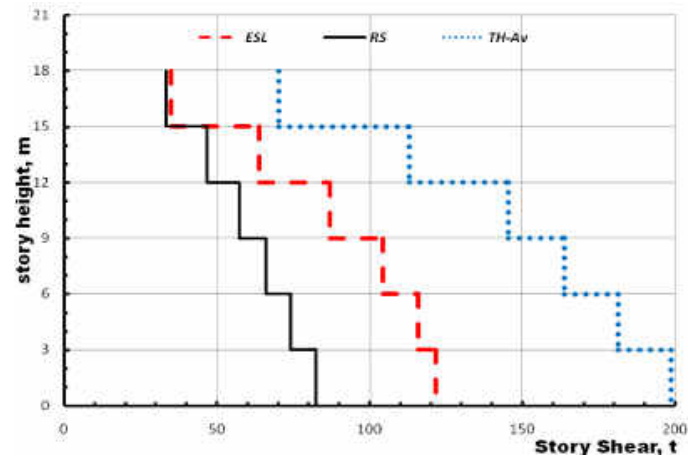

a) NSSI-1

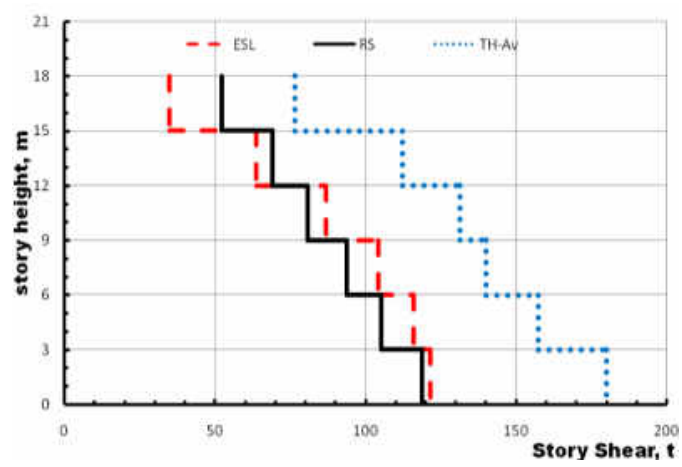

c) SSI-2

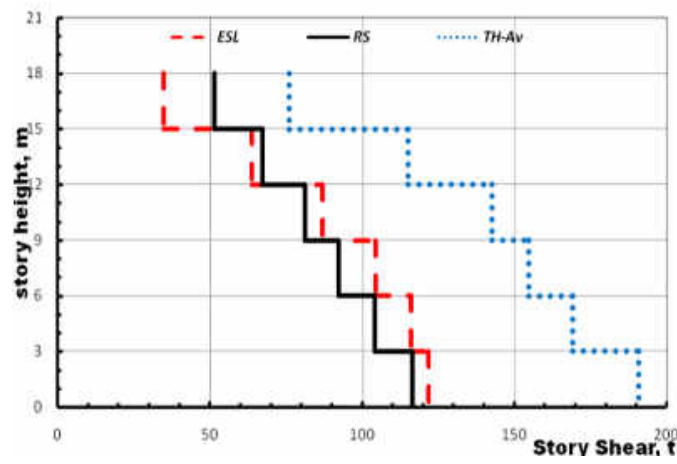

b) SSI-1

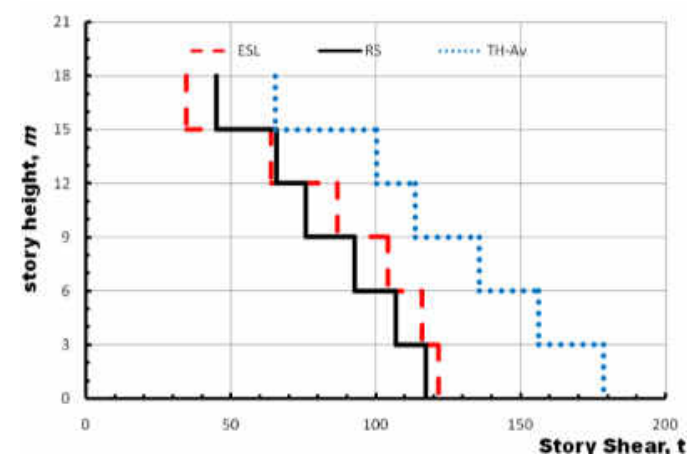

d) SSI-3

Fig. 12. Story shear force responses of 6-story building

Figs. 12 (a, b, c, d) show the story shear response profile over building height of 6story models. The maximum base shear values for NSSI-1, SSI-1, SSI-2 and SSI-3 models using equivalent static load method are constant value of $121.64 \mathrm{t}$, while using response spectra methods are $82.5 \mathrm{t}, 116.39 \mathrm{t}, 118.73 \mathrm{t}$ and $117.18 \mathrm{t}$, respectively and using time history method, the average value of nine earthquake ground motion records are $198.62 \mathrm{t}$, 190.78 t, 180.12 t and 178.57 t, respectively. For RS analysis, as the soil spring stiffness decrease, the story shears increase. For ESL analysis, story shear is not sensitive to the 
foundation soil flexibility. For TH analysis, as the soil spring gets softer, the story shears decrease. Story shear from TH analysis is higher than ESL and RS analysis.

Figs. $13(\mathbf{a}, \mathbf{b}, \mathbf{c})$ show story shear response ratio of SSI models compared to that of fixed base model for 6-story buildings. Response ratio of story shear under ESL analysis equals one for all models. The maximum response ratio of SSI-1, SSI-2 and SSI-3, using response spectra method are $1.53,1.56$ and 1.44 , respectively and using time history method, the average value of nine earthquake ground motion records are 1.08, 1.09 and 0.9 , respectively.

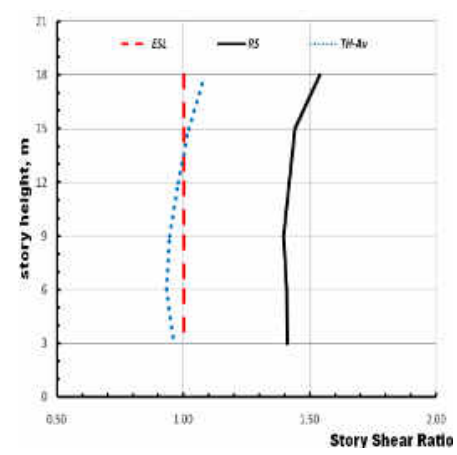

a) SSI-1

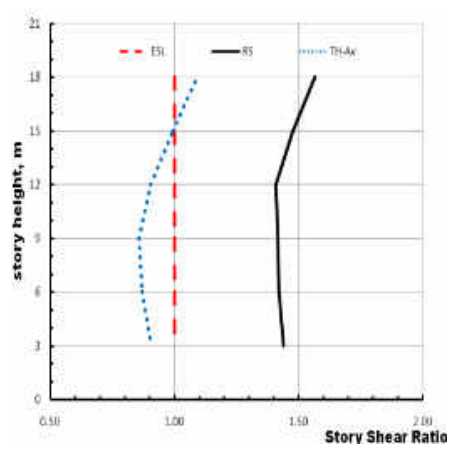

b) SSI-2

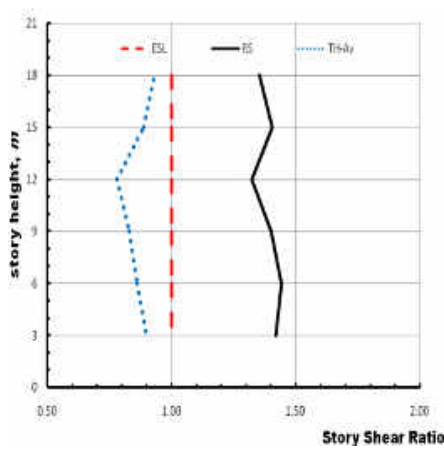

c) SSI-3

Fig. 13. Story shear ratio of SSI reference to NSSI model of 6-story building

Figs. 14 (a, b, c, d) show that story shear response profile over building height of 12story models. The maximum base shear values for NSSI-2, SSI-4, SSI-5 and SSI-6 models using equivalent static load method are constant value of $186.24 \mathrm{t}$, and using response spectra method are 163.9 t, 233.34 t, $233.81 \mathrm{t}$ and $234.93 \mathrm{t}$, respectively and using time history method the average value of nine earthquake ground motion records are $211.5 \mathrm{t}, 209.46 \mathrm{t}$, $196.92 \mathrm{t}$ and $185.41 \mathrm{t}$, respectively. For the RS analysis, as the soil spring stiffness decrease, the story shears increase. For the ESL analysis, story shear is not sensitive to the foundation soil flexibility. For TH analysis, as the soil spring gets softer, the story shears decrease. Story shear from the TH analysis is higher than the ESL and RS analysis.

Figs. 15 (a, b, c) show the story shear response ratio of SSI models compared to that of fixed base model of 12-story buildings. Response ratio of story shear under the ESL analysis equals one for all models. The maximum response ratio of SSI-4, SSI-5 and SSI-6, using response spectra methods are $1.53,1.50$ and 1.54 , respectively and using time history method, the average value of nine earthquake records are 1.2, 1.17 and 1.23, respectively. 
JES, Assiut University, Faculty of Engineering, Vol. 42, No. 4, July 2014, pp. 905 - 930

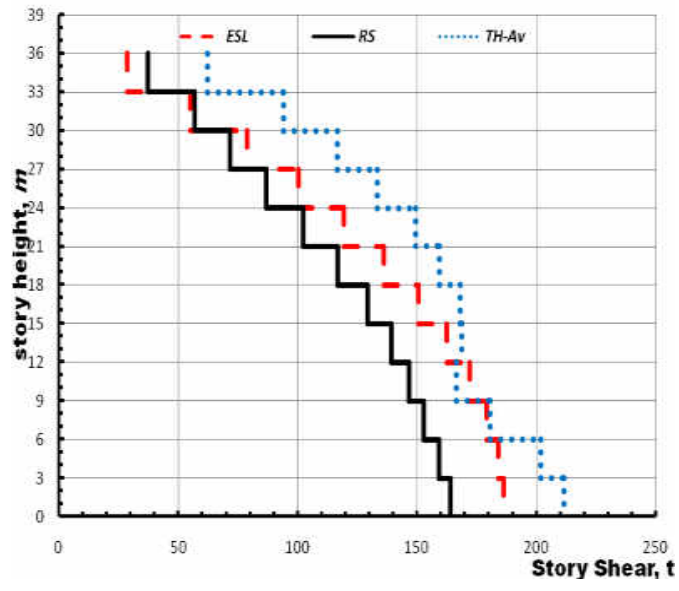

a) NSSI-2

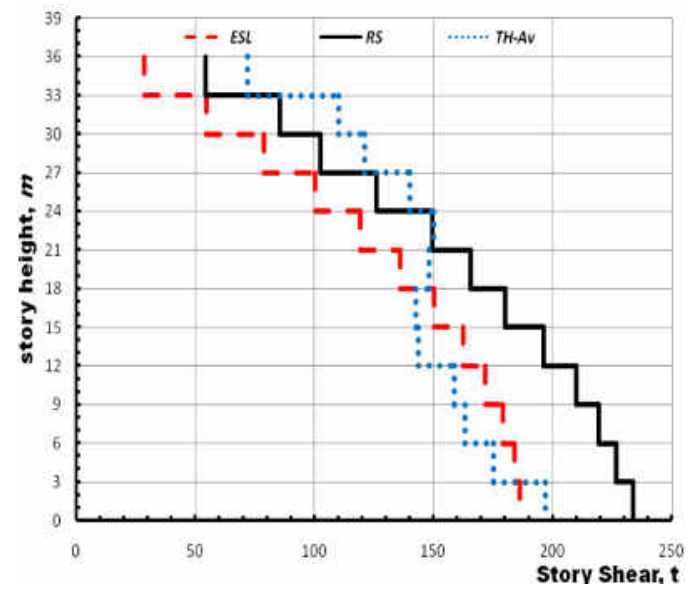

c) SSI-5

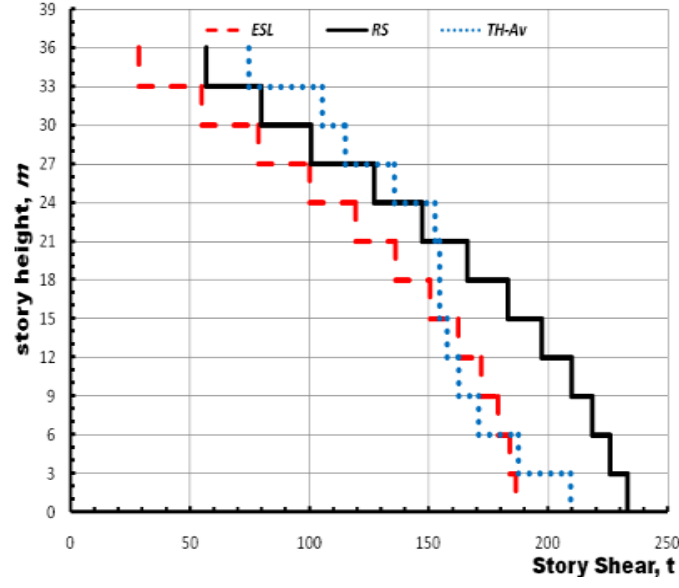

b) SSI-4

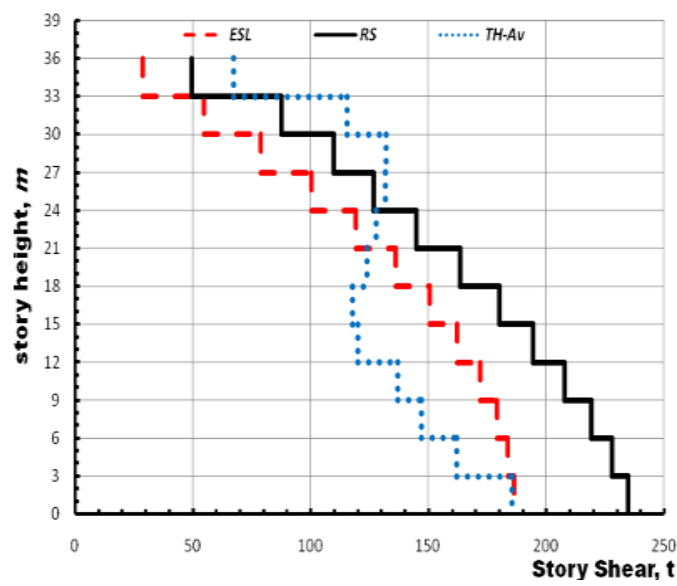

d) SSI-6

Fig. 14 Story shear force responses of 12-story building

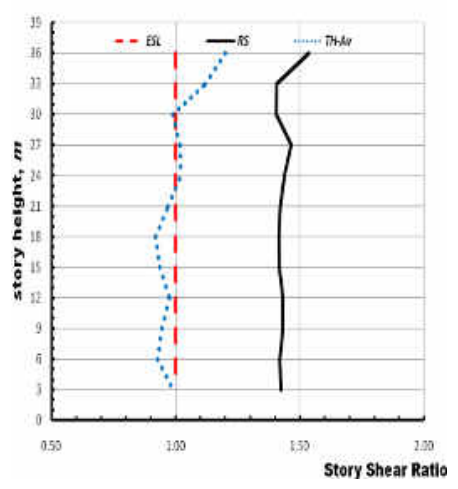

a) SSI-4

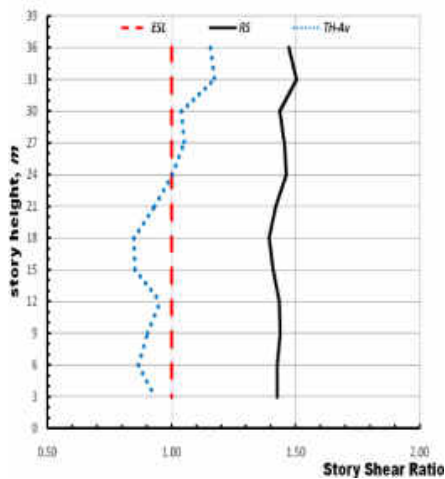

b) SSI-5

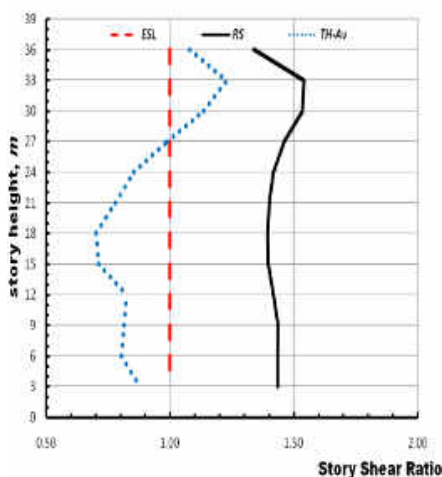

c) SSI-6

Fig. 15. Story shear ratio of SSI reference to NSSI model of 12-story building 
Shehata E Abdel Raheem et al., Soil-structure interaction effects on seismic response of multi....

\section{Summary and conclusions}

The study as a whole may prove useful in formulating design guidelines for seismic design of building frames incorporating the effect of soil-flexibility. In this study, the effects of seismic soil-structure interaction are analyzed for typical multi-story building resting on raft foundation, the influence of parameters of slab-column structure-raft foundation-soil model of a practical engineering is carried using three methods of analysis, time history $(\mathrm{TH})$ analysis with a suite of nine time history records, the equivalent static load (ESL) and the response spectrum (RS) methods, which are adopted in the Egyptian code for loads and forces (ECP-201; 2008). A mathematical model for the complete building-foundation-soil system is developed to determine the response quantities not directly available from the records and to ascertain the effects of interaction. The model is calibrated using the dynamic properties of the building as determined from the processed records. The evaluation of SSI is performed through comparison with the results obtained with those from fixed base assumption. The main findings of the study are summarized as follows:

For all models (NSSI and SSI models), The empirical expression for calculating the fundamental period of vibration using ECP-201 (2008) underestimates the fundamental period compared to the models. The structural model provides larger fundamental period than that calculated from the ECP-201 (2008) empirical expression. As the soil spring stiffness increases, the fundamental period of the structural model decreases, this means that the fundamental period is not only a function of building height but also is a function of SSI. The fundamental period calculated from the SSI models are larger than the fundamental period calculated from the NSSI models (fixed base models). This means that the change in soil stiffness could have a significant effect on the fundamental period of vibration. The variation of soil foundation flexibility affects the seismic demands on the whole structure. Soft soil model displays higher floor displacements compared to that of models of rigid soil/fixed base assumption. The SSI effects are amplified as the number of stories increase. The code empirical methods underestimate the fundamental natural period of structures using SSI. This effect on period calculation means that the design forces are likely to be overestimated, which is conservative.

The story shear response calculated from the ESL method is independent from the SSI effects and depends only on the building weight. On the contrary, the story shear responses calculated from the RS and TH methods are highly dependent on the foundation and underneath soil stiffness. Story drift response ratio increases as the soil stiffness deceases. Story drifts response ratio increases with increasing the number of stories. Lower and upper stories are more affected than middle stories considering the SSI method; this effect is amplified as the soil stiffness decreases. The story displacement response increases as the soil stiffness decease. Story displacement response ratio increases with the increase of the number of stories. Lower stories displacements are more affected than the rest stories when using the SSI method.

The model is then used to evaluate the effects of soil-structure interaction on the maximum base shear force, overturning moment and displacement for the MRF multistory buildings. The analysis demonstrates that soil-structure interaction has a significant effect on the base forces and roof displacement of the building compared to the typical assumption in which interaction would be neglected. When the ground is stiff enough, the dynamic response of the structure will not be influenced significantly by the soil properties 
JES, Assiut University, Faculty of Engineering, Vol. 42, No. 4, July 2014, pp. 905 - 930

during the earthquake, and the structure can be analyzed under the fixed base condition. When the structure is resting on a flexible medium, the dynamic response of the structure will be different from the fixed base condition owing to the interaction between the soil and the structure. It is concluded that the dynamic soil-structure interaction plays a considerable role in seismic behavior of mid-rise building frames including substantial increase in the lateral deflections and inter-story drifts and changing the performance level of the structures. Thus, considering soil-structure interaction effects in the seismic design of mid-rise moment resisting building frames, particularly when resting on soft soil deposit, is essential. If the SSI method is not taken into account in analysis and design properly; the accuracy in assessing the structural safety, facing earthquakes, could not be reliable. The conventional design procedures excluding the SSI method may not be adequate to guarantee the structural safety of regular mid-rise moment resisting building frames resting on soft soil deposits.

\section{REFERENCES}

[1] NRC-National Research Council (2004), "Preventing Earthquake Disasters: The Grand Challenge in Earthquake Engineering: A Research Agenda for the Network for Earthquake Engineering Simulation (NEES): The National Academies Press, Washington, DC.

[2] Gu Q. (2008), "Finite Element Response Sensitivity and Reliability Analysis of SoilFoundation-Structure-Interaction (SFSI) Systems", University of California, San Diego.

[3] Ashford SA, Jakrapiyanun W, Lukkunaprasit P (2000), "Amplification of earthquake ground motions in Bangkok" 12th World Conference on Earthquake Engineering,12WCEE, Auckland, New Zealand, 30 January - 4 February, paper ID 1466.

[4] Chávez-García FJ, Aguirre J (2012), "Exploration of subsoil structure in Mexico city using correlation of micrometremors," Geofísica internacional, 51(3), 251-270.

[5] Abdel Raheem S.E. (2013), "Evaluation of Egyptian Code Provisions for Seismic Design of Moment Resisting Frames Multi-Story Buildings", International Journal of Advanced Structural Engineering, 5:20, 1-18.

[6] Yao MM (2010), "Earthquake wave-soil- structure interaction analysis of tall buildings," Ph.D. Thesis, University of Victoria, Canada, AAT NR74121.

[7] El-Sayed H.E. (2005), "Earthquake Nonlinear Modeling of R.C Building Including Foundation-Soil Interaction", Zagazig university, Egypt.

[8] Pitilakis K, Anastasiadis A, and Raptakis D (1992), "Field and laboratory determination of dynamic properties of natural soil deposits", 10th World Conference of Earthquake Engineering, Madrid, Spain, 1275-1280.

[9] Kourkoulis R, Anastasopoulos I, Gelagoti F, Kokkali P (2012), "Dimensional analysis of SDOF systems rocking on inelastic soil", Journal of Earthquake Engineering, 16(7), 995-1022.

[10] ECP-201 (2008), "Egyptian Code for Calculating Loads and Forces in Structural Work and Masonry", Housing and Building National Research Center, Ministry of Housing, Utilities and Urban Planning, Cairo, Egypt.

[11] Ozturk M (2013), "Field Reconnaissance of the October 23, 2011 Van, Turkey Earthquake $(\mathrm{Mw}=7.2)$ : Lessons Learned from Structural Damages", Journal of Performance Constructed Facilities, 10.1061/(ASCE)CF.1943-5509.0000532 (Oct. 31, 2013)

[12] Abdel Raheem K.A., Abdel Raheem S.E., Soghair H.M. and Ahmed M.H. (2010), "Evaluation of seismic performance of multistory buildings designed according to Egyptian code", Journal of Engineering Sciences, Assiut University, 38(2), 381-402. 
Shehata E Abdel Raheem et al., Soil-structure interaction effects on seismic response of multi....

[13] Khater M. (1992), "Reconnaissance report on the Cairo, Egypt earthquake of October 12, 1992", NCEER-92-0033, 23 December, 52 pages.

[14] Badawi H.S. and Mourad S.A. (1994), "Observations from the 12 October 1992 Dahshour earthquake in Egypt", Natural Hazards journal, 10(3), 261-274.

[15] Mourad S.A., Elattar A.G., Megahid H.A., Hosny A.H., Elthahaby K.M. and Riad S. (2000), "Assessment of seismic effects on structures in Egypt and measures for mitigation", An Arabic study for the National Academy for Scientific Research and Technology.

[16] UBC (1997), "Uniform Building Code, Vol. 2: Structural Engineering Design Provisions", International Conference of Building Officials (ICBO), Whittier, California.

[17] AIJ (1999), "Design Guidelines for Earthquake Resistant Reinforced Concrete Structures", Architectural Institute of Japan, Tokyo.

[18] SEAOC (1999), "Recommended Lateral Force Requirements and Commentary"' Seismology Committee, Structural Engineers Association of California (SEAOC), $7^{\text {th }}$ Edition

[19] IBC (2003), "International Building Code International Code Council", West Flossmoor Road, Country Club Hills, USA

[20] EC8 (2004), "Eurocode 8 - Design of Structures for Earthquake Resistance. Part 1: General Rules, Seismic actions and rules for buildings", European Committee for Standardization, EN 1998-1", Brussels, Belgium.

[21] ASCE (2005), "Building code requirements for structural concrete (ASCE318-05) and Commentary (ASCE318R-05)", American Concrete Institute, Farmington Hills, MI, USA.

[22] ECP-203 (2007), "Egyptian Code for Design and Construction of Reinforced Concrete Structures, ECPCS-203", Housing and Building National Research Center, Ministry of Housing, Utilities and Urban Planning, Cairo, Egypt.

[23] ATC (1978), "Tentative provisions for the development of seismic regulations for buildings", Report No. ATC3-06, Applied Technology Council, Palo Alto, CA.

[24] ATC (1996), "Seismic Evaluation and Retrofit of Concrete Buildings", Report ATC-40, Applied Technology Council, Redwood City, U.S.A.

[25] FEMA 451B. (2007), "NEHRP Recommended Provisions", FEMA 451B

[26] FEMA-356 (2000), "Pre-standard and commentary for the seismic rehabilitation of buildings", American Society of Civil Engineers (ASCE), Federal Emergency Management Agency, Washington, DC, U.S.A.

[27] Chopra AK, (1995) "Dynamics of Structures Theory and Application to Earthquake Engineering", University of California at Berkeley, USA

[28] Paz M. and Leigh W.E. (2003), "Structure Dynamics Theory and Computation”, Springer 5th edition, ISBN 139781402076671.

[29] Thuat D.V. (2012), "Strength reduction factor demands for building structures under different seismic levels", The Structural Design of Tall and Special Buildings, DOI: 10.1002/tal.1018.

[30] Crowley H. and Pinho R. (2010), "Revisiting Eurocode 8 formulae for periods of vibration and their employment in linear seismic analysis", Earthquake Engineering and Structural Dynamics, 39, 223-235.

[31] Kunnath S.K. and Kalkan E. (2004), "Evaluation of Seismic Deformation Demands Using Non-linear Procedures in Multistory Steel and Concrete Moment Frames" ISET Journal of Earthquake Technology, 41(1), 159-181, Paper No. 445.

[32] NBCC (2005), "National Building Code of Canada", $12^{\text {th }}$ ed, Canadian Commission on Building and Fire Codes, National Research Council of Canada (NRCC), Ottawa, Ont.

[33] Kharade A.S., Kapadiya S.V., Belgaonkar S.L. (2013),"Earthquake Analysis of Tall Sky-Pod Structures by Considering the Soil Structure Interaction Effect", International Journal of Emerging Technology and Advanced Engineering, 3(1), 447-454. 
[34] Algreane G.A., Osman S.A, Karim O.K, Kasa A.(2011)," Behavior of Elevated Concrete Water Tank Subjected to Artificial Ground Motion", Electronic Journal of Geotechnical Engineering-EJGE, 16 , Bund. D.

[35] ASTM (1985), "Classification of Soils for Engineering Purposes: Annual Book of ASTM Standards", D 2487-83, 04.08, American Society for Testing and Materials, 395-408.

[36] Gazetas G. (1991), "Formulas and charts for impedances of surface and embedded foundations", Journal of Geotechnical Engineering, 117(9), 1363-1381.

[37] Mylonakis G., Nikolaou S., Gazetas G. (2006), "Footings under seismic loading: analysis and design issues with emphasis on bridge foundations", Soil Dynamics and Earthquake Engineering, 26(9), 824-853.

[38] Kalkan E. and Chopra A.K. (2010), "Practical Guidelines to Select and Scale Earthquake Records for Nonlinear Response History Analysis of Structures", U.S. Geological Survey Open-File Report, 113 p.

[39] Computers \& Structures Inc. (2011), "Extended Three dimensional Analysis of Building Systems (ETABS)", Computer Software Package, Version 9.7.4, Berkeley US-CA.

[40] Computers \& Structures Inc. (2011), ETABS, Integrated Finite Element Analysis and Design of Structures, User's Manual, CSI, Berkeley, California.

[41] Computers and Structures Inc. (2003), "SAP2000: Integrated Software for Structural Analysis and Design", Computers and Structures, Inc. (http://csiberkeley.com), Berkeley, CA, U.S.A.

[42] Computers and Structures Inc. SAP2000 Advanced 11.0.8. Static and Dynamic Finite Element Analysis of Structures, Berkeley, 2007.

[43] Computers and Structures, Inc., ETABS: integrated building design software, v.9.7 - user's manual. Berkeley, California, USA, 2003.

[44] PEER (2012), "Strong Motion Database", The Pacific Earthquake Engineering Research Center, http://peer.berkeley.edu/smcat/search.html.

[45] Kwon O. and Kim E.S. (2010), "Evaluation of building period formulas for seismic design", Earthquake Engineering and Structural Dynamics, 39, 1569-1583 


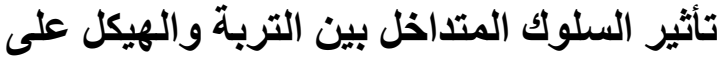

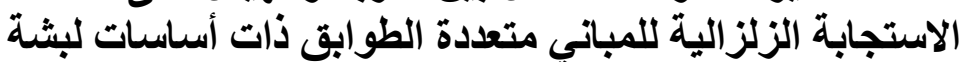

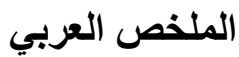

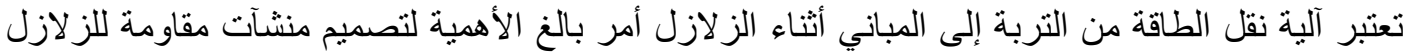

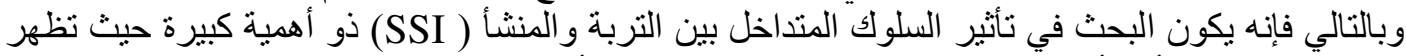

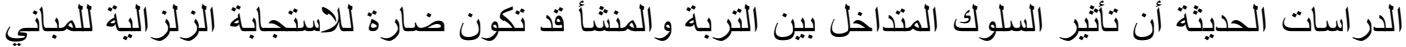

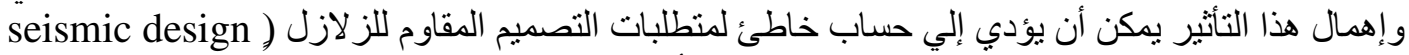

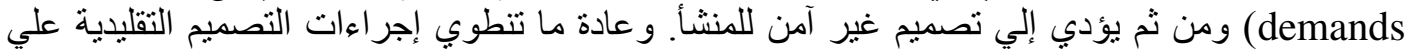

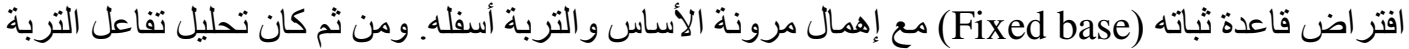

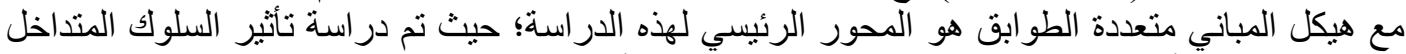

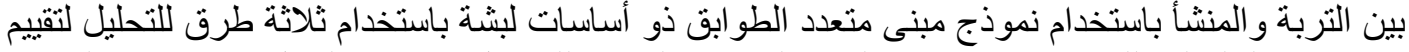

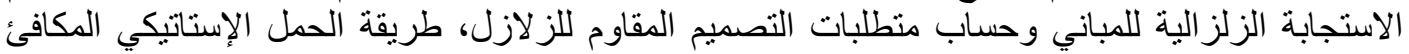

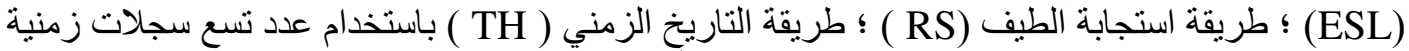

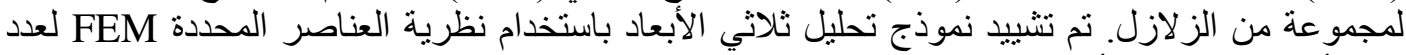

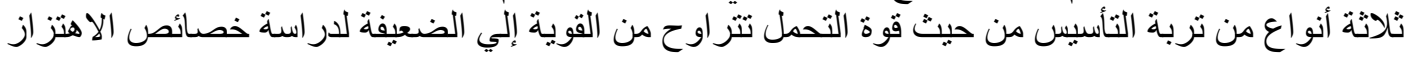

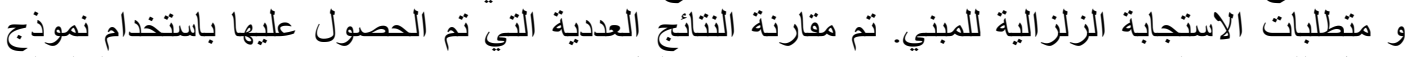

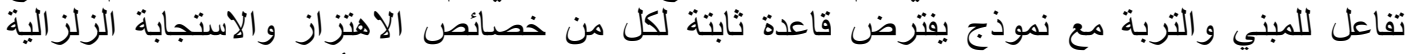

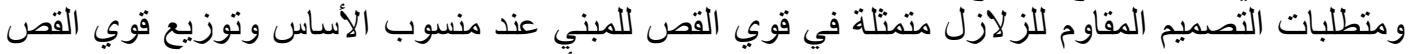

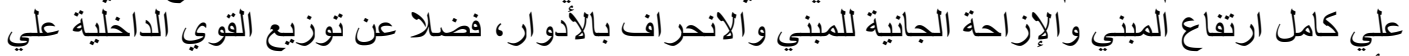

